\title{
Adsorption Capacity of Smectite Clay and Its Thermal and Chemical Modification for Two Anionic Dyes: Comparative Study
}

\author{
Magdalena Pajak (D)
}

Received: 17 November 2020 / Accepted: 27 January 2021/Published online: 15 February 2021

(C) The Author(s) 2021

\begin{abstract}
The present research evaluates the influence of modification of smectite clay (BC) on its adsorption capacity of anionic dyes from aqueous solutions. Thermal (BC 250), acidic ( $\mathrm{BC} \mathrm{H}_{2} \mathrm{SO}_{4}$ ), and alkaline (BC $\mathrm{NaOH})$ modification of clay was carried out. The clays were characterized by X-ray powder diffraction, energydispersive X-ray spectroscopy, and Fourier transform infrared spectroscopy. Adsorption of dyes was investigated by batch experiments at room temperature $(23 \pm 2$ ${ }^{\circ} \mathrm{C}$ ), a wide range of initial dye concentrations (1-1000 $\mathrm{mg} / \mathrm{dm}^{3}$ ), and an adsorbent dose of $50 \mathrm{~g}$. All modifications increased the clay's adsorption capacity for Reactive Red 198, in the order $\mathrm{BC}_{2} \mathrm{SO}_{4}>\mathrm{BC} \mathrm{NaOH}>\mathrm{BC}$ $250>\mathrm{BC}$; it was $10.32,5.06,3.32$, and $2.92 \mathrm{mg} / \mathrm{g}$, respectively. Acid and thermal modification of the clay increased its adsorption capacity for Acid Red 18, in the series $\mathrm{BC}_{2} \mathrm{SO}_{4}>\mathrm{BC} 250>\mathrm{BC}>\mathrm{BC} \mathrm{NaOH}$; it was $3.07,2.66,2.16$, and $1.28 \mathrm{mg} / \mathrm{g}$, respectively. The experimental data were analyzed by Freundlich, Langmuir, Dubinin-Radushkevich, and Sips isotherms, using nonlinear regression. The experimental data best fitted the Sips isotherm. Taking into account the structure of the adsorbent and adsorbates and the results obtained, it can be concluded that the dyes were probably bound through chemisorption, by forming hydrogen bonds between $\mathrm{Si}-\mathrm{OH}$ and $\mathrm{Al}-\mathrm{OH}$ groups in the clay and $-\mathrm{NH},-\mathrm{NH}_{2}$, and $-\mathrm{OH}$ groups in the dyes. From the
\end{abstract}

M. Pajak $(\bowtie)$

Institute of Environmental Engineering Polish Academy of Science, 34 M. Skłodowskiej-Curie Street, 41-819 Zabrze, Poland e-mail: magdalena.pajak@ipis.zabrze.pl results obtained, it can be concluded that smectite clay is a promising material for dye adsorption.

Keywords Adsorption · Clay · Anionic dyes · Isotherms

\section{Introduction}

Water is a unique substance without which life on Earth could not exist. One of the most serious aquatic environment problems in modern society is pollution of water by synthetic dyes (Malakootian et al. 2015; Banaei et al. 2017; Kyziol-Komosinska et al. 2018). Synthetic dyes are widely used in dyeing processes, especially in textile dyeing, tanning, paper, cosmetics, food, iron, steel, and plastics, etc. (Özcan et al. 2005; Errais et al. 2010; Nejib et al. 2015; Adeyemo et al. 2017; Chaari et al. 2019). Due to their chemical structure, dyes belong to groups such as azo, anthraquinone, oxazine, acridine, formazan, phthalocyanine, thiazine, triphenylmethane, triarylmethane, nitroso, and nitro compounds, etc., and due to their application to reactive, acidic, cationic, direct, vat, disperse, solvent, and sulfur groups. Azo compounds are the largest group of organic-synthetic dyes; they consist of a diazotized amine coupled to an amine or a phenol and contain one or more azo $(-\mathrm{N}=\mathrm{N})$ linkages (Forgacs et al. 2004; Ventura-Camargo and Marin-Morales 2013; Hai et al. 2015; Malakootian et al. 2015; Chaari et al. 2019; Mishra and Maiti 2019; Mishra et al. 2020). Among the azo dyes, the most commonly used in the textile industry are reactive dyes. Due to their high water 
solubility and low degradability, reactive dyes are one of the most problematic pollutants found in wastewater from the textile industry. Reactive dyes are hydrophilic and therefore have little tendency to adsorption in biological biomass processing methods. Furthermore, these dyes have a high molecular weight, have aromatic rings, and are toxic to living organisms. Moreover, they are often stable, resistant to degradation, toxic, carcinogenic, and mutagenic. These dyes have a complex chemical structure, which can cause serious health problems such as allergies and dermatological diseases (Aksakal and Ucun 2010; Gao et al. 2013; Malakootian et al. 2015; Banaei et al. 2017). It is therefore necessary to effectively remove reactive dyes from wastewater before discharge into the sewerage system and the environment.

Many methods are known for removing dyes from wastewater from the textile industry, such as membrane filtration, ion exchange, electrochemical techniques, coagulation and flocculation, reverse osmosis, chemical oxidation, ozonation, biological treatment including activated sludge, and bacterial action (Robinson et al. 2001; Saffaj et al. 2004; Kim et al. 2005; Raghu et al. 2009; Szygula et al. 2009; Labanda et al. 2011; Gadekar and Ahammed 2015; Hassan and Carr 2018; Mishra and Maiti 2020). Among these methods, adsorption is one of the most effective for removing dyes from wastewater (Huang et al. 2007; Aguiar et al. 2017; Kausar et al. 2018). This method is characterized by high efficiency, simplicity of construction, ease of use, and flexibility, and - very importantly - compared to other methods is economical. The best known and most commonly used adsorbent is activated carbon, which has a high adsorption capacity. However, the main disadvantage of using activated carbon as a sorbent is its high cost (Jain et al. 2003; Kyziol-Komosinska et al. 2018). There is a need to search for alternative, relatively cheaper adsorbents that can be used to control water pollution. In recent years, many studies have been conducted on the adsorption capacity of materials in relation to organic pollutants, such as natural, waste, and synthetic materials (Tanyildizi 2011; Bharathi and Ramesh 2013; Vieira et al. 2014; Bello et al. 2015; Nejib et al. 2015; Amaral et al. 2016; Dotto et al. 2016; Mirzaei et al. 2016; Franciski et al. 2018; Dzieniszewska et al. 2019; Mishra et al. 2021). Among these, clay minerals deserve particular attention due to their easy availability, nontoxicity, large surface area, high swelling capacity, high cation capacity, and the presence of several types of active sites on the surface. The most commonly used clay minerals are kaolinite, illite, and smectite (Errais et al. 2011; Errais et al. 2012; Santos and Boaventura 2016; Ngulube et al. 2017; Gamoudi and Srasra 2019).

The best known and most commonly used industrial clay minerals are smectites. They are defined as the group of phyllosilicates with a layer charge of between 0.4 and $1.2 \mathrm{e}^{-}$per unit cell, arising from the nonequivalent substitution of central atoms in layers with lower valence cations (Madejova et al. 1998). The smectite group refers to a family of non-metallic clays primarily composed of hydrated sodium calcium aluminum silicate, a group of monoclinic clay-like minerals with the general formula $(\mathrm{Ca}, \mathrm{Na}, \mathrm{H})(\mathrm{Al}, \mathrm{Mg}, \mathrm{Fe}$, $\mathrm{Zn})_{2}(\mathrm{Si}, \mathrm{Al}) 4 \mathrm{O}_{10}(\mathrm{OH})_{2} \cdot n \mathrm{H}_{2} \mathrm{O}$, and chemically it is hydrated sodium calcium aluminum magnesium silicate hydroxide $(\mathrm{Na}, \mathrm{Ca})_{x}(\mathrm{Al}, \mathrm{Mg})_{2}\left(\mathrm{Si}_{4} \mathrm{O}_{10}\right)(\mathrm{OH})_{2} \cdot n \mathrm{H}_{2} \mathrm{O}$ (Kausar et al. 2018). The 2:1 structure of smectites is formed by two tetrahedral sheets linked with an octahedral sheet. The tetrahedral sheets are built of $\mathrm{T}_{2} \mathrm{O}_{5}$ units and as the central atom contain $\mathrm{Si}, \mathrm{Al}$, or Fe. In smectites' structure, there occur two types of octahedral sheet, i.e., the dioctahedral type, where two-thirds of the octahedral sites are occupied mainly by trivalent cations, e.g. $\mathrm{Al}(\mathrm{III})$ or $\mathrm{Fe}$ (III), and the trioctahedral type, with most of the sites occupied by divalent cations, e.g., $\operatorname{Mg}$ (II) (Tamayo et al. 2012). The negative surface layer charge, resulting from the isomorphous substitution of $\mathrm{Mg}^{2+}$ or $\mathrm{Fe}^{2+}$ for octahedral $\mathrm{Al}^{3+}$ or $\mathrm{Fe}^{3+}$ and $\mathrm{Al}^{3+}$ for tetrahedral $\mathrm{Si}^{4+}$, causes binding of exchangeable cations to the interlayer sites. The charge of the smectite packet per unit cell is relatively small, which means that the cations are weakly bound in interpackage spaces and can be exchanged for other cations. This feature is extremely important because it allows for various structural modifications (Kyziol-Komosinska et al. 2010).

There have been numerous studies on the adsorption capacity of clays in relation to cationic dyes, especially methylene blue (Gürses et al. 2006; Nethaji et al. 2013; Santos and Boaventura 2016; Omer et al. 2018; Chaari et al. 2019). The novelty of these studies was the determination of the adsorption capacity of natural and thermally, acid- and alkaline-modified clay in relation to anionic dyes. The aim of this study was to determine the influence of clay modification on the adsorption capacity of anionic dyes from aqueous solutions. The adsorption studies were carried out on prepared model solutions of artificial anionic dyes and not on real wastewater samples. The use of distilled water eliminates any additional matrix effects and allows changes to 
individual parameters and determination of their influence on the adsorption properties of the tested clay. In industrial wastewater, in addition to dye, there are also significant quantities of auxiliary substances, such as salts, which are present in wastewater in concentrations similar to those during application. Salts that can affect the adsorption capacity of fibers by changing their surface charge and changing the ionic nature, hydrophobicity, and solubility of the dye are often used in dyeing processes, which may have an adverse effect on test results. Their presence can have a negative impact on the results of laboratory tests.

Four isotherms of adsorption, i.e., Freundlich, Langmuir, Dubinin-Radushkevich, and Sips, were used to understand the nature of the adsorption process, and the estimation of parameters allowed determination of the maximum adsorption capacity and dye-binding mechanisms.

\section{Materials and Methods}

\subsection{Preparation and Characterization of Clay}

Smectite clay from the "Belchatow" lignite deposit (BC), obtained from the Belchatow Lignite Mine, Central Poland, was used for laboratory studies as an adsorbent (Fig. 1). The clay was dried at room temperature $\left(25 \pm 2{ }^{\circ} \mathrm{C}\right)$ and then ground to a fraction $<0.5 \mathrm{~mm}$. Subsequently, modification of clay-thermal (BC 250), acidic $\left(\mathrm{BC}_{2} \mathrm{SO}_{4}\right)$, and alkaline $(\mathrm{BC} \mathrm{NaOH})$ - was carried out.

The thermal modification consisted of heating the clay samples in an oven at $250{ }^{\circ} \mathrm{C}$ for $5 \mathrm{~h}$. The acid modification of clay was carried out accordance with Stoch et al. (1977), using a $16 \% \mathrm{H}_{2} \mathrm{SO}_{4}$ solution at 96 ${ }^{\circ} \mathrm{C}$, for $8 \mathrm{~h}$, with a solution to solid phase ratio of $5: 1$. After $2 \mathrm{~h}$, the used acid was replaced by fresh acid to avoid the precipitation of $\mathrm{CaSO}_{4}, \mathrm{MgSO}_{4}$, and $\mathrm{FeSO}_{4}$ salts. After cooling down, the samples were washed with distilled water until the reaction to $\mathrm{SO}_{4}{ }^{2-}$ ion disappeared; then the samples were centrifuged and then dried at $105{ }^{\circ} \mathrm{C}$. The alkaline modification was performed using $5 \mathrm{M} \mathrm{NaOH}$ solution at $90{ }^{\circ} \mathrm{C}$, for $8 \mathrm{~h}$, with a solution to solid phase ratio of $5: 1$. Then the clay samples were washed with distilled water until they disappeared in the $\mathrm{Na}^{+}$ion solution and were dried at $105^{\circ} \mathrm{C}$ (Öztop and Shahwan 2006).
The clay samples were characterized by X-ray powder diffraction (XRD), energy-dispersive X-ray spectroscopy (ED-XRF), and Fourier transform infrared spectroscopy (FT-IR).

Determination of mineral composition was carried out by XRD analysis using a Philips APD PW 3020 $\mathrm{X}$ 'Pert diffractometer, which was equipped with a graphite monochromator using $\mathrm{Cu}-\mathrm{K} \alpha$ radiation. The XRD patterns were registered in the range of $2-73^{\circ}$ $2 \theta$, with a step of $0.05^{\circ} 2 \theta$.

The functional groups of clay were determined by infrared spectroscopy using a Fourier transform infrared spectrometer (Nicolet Magna FT-IR spectrometer).

The chemical composition of the clay was determined by X-ray fluorescence spectrometry (ED-XRF) using a Philips PW 1404 sequential spectrometer.

The specific surface area (SSA) was determined by the BET method from the nitrogen adsorption isotherms at $77 \mathrm{~K}$ and water adsorption isotherms at room temperature (Fisons, Sorptomatic 1990).

The porosity and pore size were determined by mercury porosimetry using a mercury intrusion porosimeter (Carlo Erba model 2000).

The $\mathrm{pH}$ values of the clays were measured in deionized water at a suspension ratio of $1: 2.5$, using a $\mathrm{pH}$ meter which is based on a combination $\mathrm{pH}$ electrode (glass membrane electrode and a reference electrode) (ERH-111 Hydromet, Poland).

The point of zero charge $\left(\mathrm{pH}_{\mathrm{PZC}}\right)$ of clay, defined as the $\mathrm{pH}$ at which the charge of the colloidal particles $=0$, was determined with the method described by Calvete et al. (2009).

\subsection{Characterization of Dyes}

Reactive Red 198 (RR 198, CAS number: 14501798-7, molecular formula: $\mathrm{C}_{27} \mathrm{H}_{18} \mathrm{ClN}_{7} \mathrm{Na}_{4} \mathrm{O}_{16} \mathrm{~S}_{5}$ ) and Acid Red 18 (AR 18, CAS number: 2611-82-7, molecular formula: $\mathrm{C}_{20} \mathrm{H}_{11} \mathrm{~N}_{2} \mathrm{Na}_{3} \mathrm{O}_{10} \mathrm{~S}_{3}$ ) dyes were selected as a model of anionic dyes for the adsorption experiments; their chemical structures, properties, wavelengths at which the absorbance was measured $(\lambda)$, and the size of the dye molecule $(d)$ are shown in Fig. 2. Anionic dyes differ in the number of acceptors and donors: RR 198 has 3 donor groups and 22 acceptor groups, while AR 18 has 1 acceptor and 12 donors. The dyes are produced by Boruta Zachem-Kolor, Ltd. (Poland). 


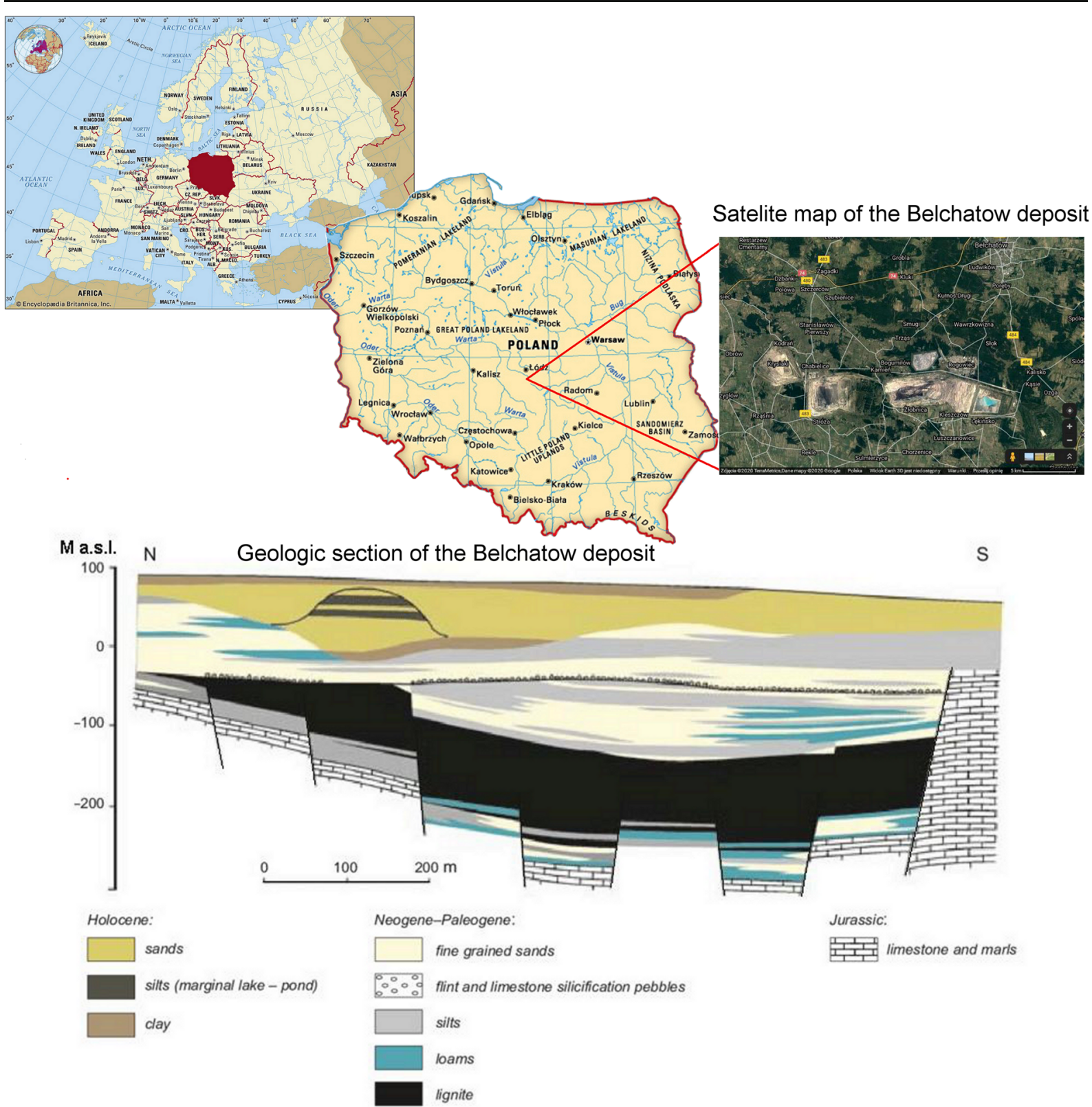

Fig. 1 Location of the Belchatow brown coal deposit (www.google.com/maps) and geologic section of the Belchatow deposit (based on Hycnar et al. 2018)

\subsection{Adsorption Experiments}

A batch experiment was carried out to measure the adsorption capacity of the natural and modified clay in relation to RR 198 and AR 18 dyes from aqueous solutions at room temperature $\left(23 \pm 2{ }^{\circ} \mathrm{C}\right)$. Clay was shaken with the aqueous solution of the dyes for 24 $\mathrm{h}$. The initial concentrations of the dyes in aqueous solution were within a wide range of $1-1000 \mathrm{mg} /$ $\mathrm{dm}^{3}$, and the ratio of solution to solid phase was 20 : 1 (adsorbent dose $50 \mathrm{~g}$ ). The initial $\left(C_{0}\right)$ and equilibrium $\left(C_{\text {eq }}\right)$ concentrations of RR 198 and AR 18 were determined using UV-vis spectrometry (Spectrometer Varian Cary 50 Scan UV-VIS) at wavelengths of $\lambda=508$ and $506 \mathrm{~nm}$, respectively. In all solutions, $\mathrm{pH}$ values were measured by potentiometric method using a glass electrode $\mathrm{pH}$ meter (Elmetron ERH-111). 

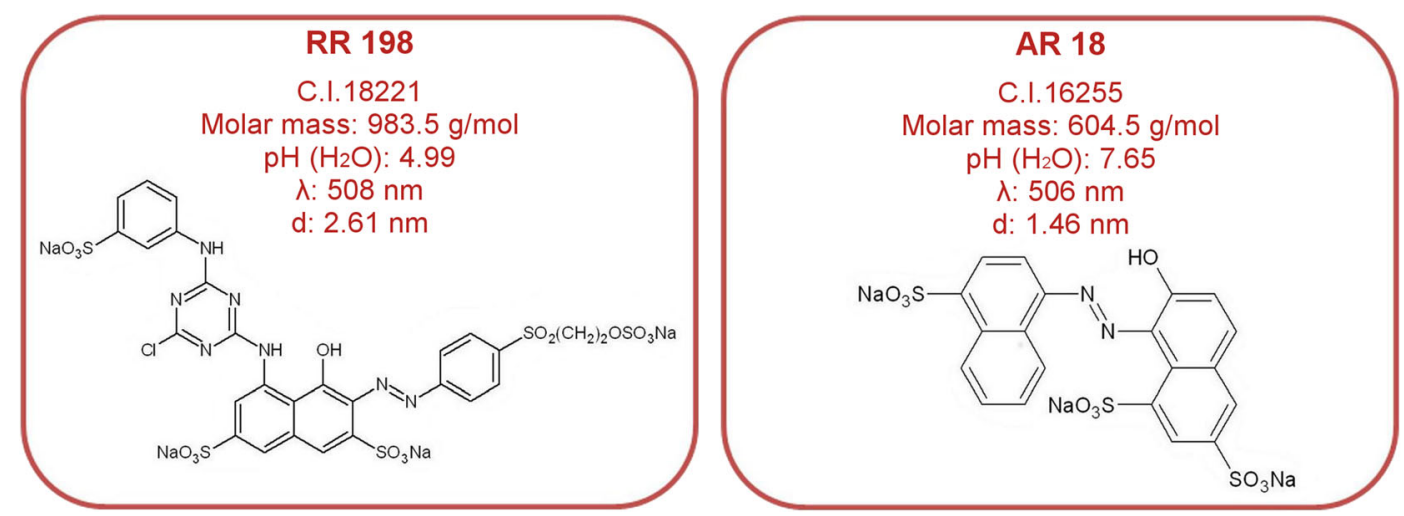

Fig. 2 Characteristics of RR 198 and AR 18 dyes

The amount of dyes adsorbed $(q)$ by the used adsorbent was calculated with Eq. 1 and the removal efficiency (RE) was calculated from Eq. 2:

$q=\left(C_{0}-C_{e q}\right) \cdot \frac{V}{m}(\mathrm{mg} / \mathrm{g})$

$\mathrm{RE}=\frac{C_{0}-C_{e q}}{C_{e q}} \cdot 100 \%(\%)$

where $C_{0}$ is the initial concentration of the dyes $(\mathrm{mg} /$ $\left.\mathrm{dm}^{3}\right), C_{\text {eq }}$ is the equilibrium concentration $\left(\mathrm{mg} / \mathrm{dm}^{3}\right), m$ is sorbent mass $(\mathrm{g})$, and $V$ is solution volume $\left(\mathrm{dm}^{3}\right)$.

All experiments were performed in triplicate.

Before the laboratory studies on dye adsorption, the influence of the dye solution $\mathrm{pH}$ on absorbance was determined. Dye solutions with concentrations of 10 and $50 \mathrm{mg} / \mathrm{dm}^{3}$ were prepared. The $\mathrm{pH}$ of the dye solutions was adjusted to $4.0,6.0$, and 8.0 by adding $0.1 \mathrm{M} \mathrm{HCl}$ solution or $0.1 \mathrm{M} \mathrm{NaOH}$ solution. The effect of the $\mathrm{pH}$ of the RR 198 and AR 18 solutions on the absorbance was then analyzed using UV-vis spectrometry (Spectrometer Varian Cary 50 Scan UV-VIS). No change in absorbance was observed on changing the $\mathrm{pH}$ of the dye solutions (Fig. 3); therefore, the calibration curve for the tested anionic dyes was made at the natural $\mathrm{pH}$ of the dye solutions.

\subsection{Adsorption Isotherm Models}

To describe the adsorption behavior in different experimental conditions is to use mathematical models which are very useful, e.g., in process optimization, and provide a lot of valuable information about the adsorption process. In order to estimate the maximum adsorption capacity of natural and modified clay and to determine the mechanisms of dye binding, four isotherm models were used, i.e., three 2-parameter models (Freundlich, Langmuir and Dubinin-Radushkevich isotherms) and one 3parameter model (the Sips isotherm). The author's previous research (Pajak et al. 2019; Pajak and Dzieniszewska 2020) has shown that the nonlinear method is a better way to obtain the isotherm parameters and represent the most suitable isotherm. Also, other researchers (Kumar and Sivanesan 2005; Nebaghe et al. 2016; Yadav and Singh 2017; Jasper et al. 2020) have come to similar conclusions during their work. Therefore, the parameters in isothermal equations were estimated using a nonlinear regression method based on the Gauss-Newton method (Statistica software v. 9.0). A description of the four isotherm models and their equations is given in Online Resource 1 (Table 1).

Nonlinear regression, based on the classical leastsquares method, was used to determine the values of parameters in the adsorption isotherms (Statistica $\mathrm{v}$. 9.0-Gauss-Newton algorithm). In order to fit isotherm models to experimental results, three error functions, the sum of the squares of the errors (SSE), residual root mean square error (RMSE), and nonlinear chi-square test $\left(\chi^{2}\right)$, were used (additional data are given in Online Resource 2-Table 2). Error functions measure the differences between the experimental data and those calculated from mathematical models; lower values of error functions (SSE, RMSE, and $\chi^{2}$ ) indicate the similarity of the values calculated based on models to those obtained experimentally and a good fit of the isotherm to the experimental data (Foo and Hameed 2010). 
Fig. 3 Effect of dye solution $\mathrm{pH}$ on absorbance

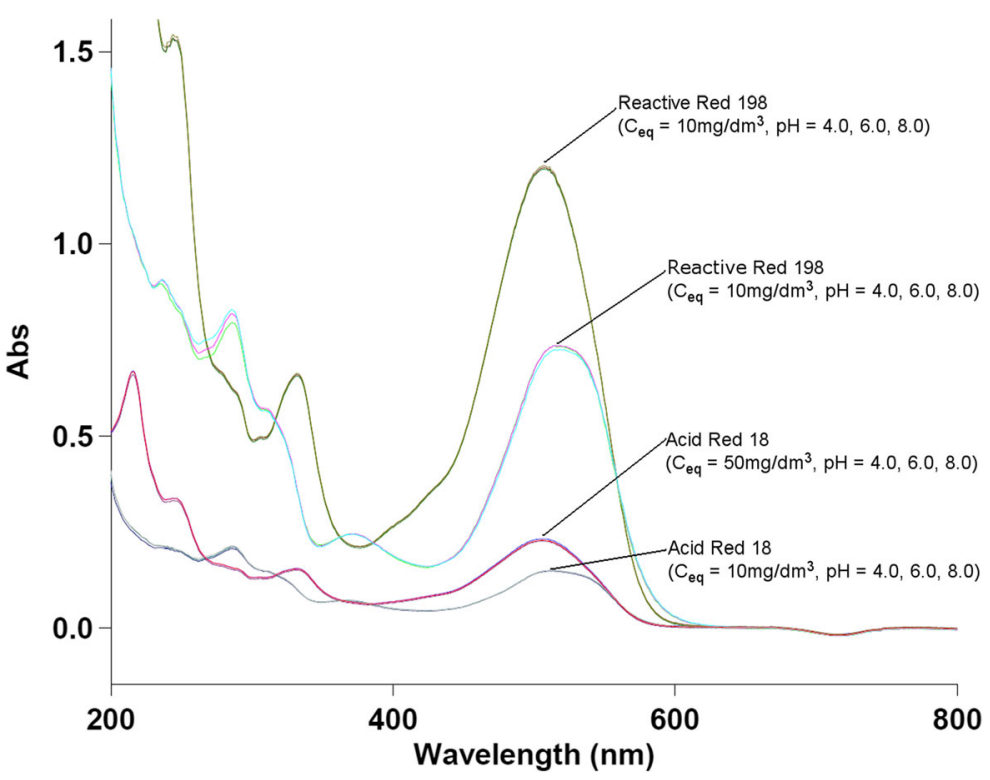

\section{Results and Discussion}

\subsection{Characterization of Natural and Modified Clays}

On the basis of X-ray analysis of the clay samples, it was observed that the main mineral was Ca-smectite. The presence of other minerals, i.e., quartz, calcite, and kaolinite, was also determined (Fig. 4). The chemical composition reflected the mineral composition of clay. The studied clay contained $\mathrm{SiO}_{2}(55.81 \%), \mathrm{Al}_{2} \mathrm{O}_{3}$
(15.25\%), $\mathrm{Fe}_{2} \mathrm{O}_{3}$ (6.45\%), $\mathrm{CaO}(2.82 \%), \mathrm{MgO}$ (1.40\%), $\mathrm{Na}_{2} \mathrm{O}(0.42 \%)$, and $\mathrm{K}_{2} \mathrm{O}(0.70 \%)$. In addition, to better present the changes occurring during modification, the ratio of silica to alumina was calculated (Table 1).

On the basis of the infrared spectrum analysis, it was observed that the main functional groups of the clay surface were dissociated silanol groups $(-\mathrm{Si}-\mathrm{O})$ in tetrahedral sheets; aluminol groups $\left(-\mathrm{Al}_{2}-\mathrm{OH}\right)$ in octahedral sheets; $-\mathrm{AlFe}-\mathrm{OH}$ groups, reflecting the partial
Fig. 4 XRD patterns of natural (BC) and thermally (BC 250), alkaline (BC NaOH)- and acid (BC $\mathrm{H}_{2} \mathrm{SO}_{4}$ )-modified clay

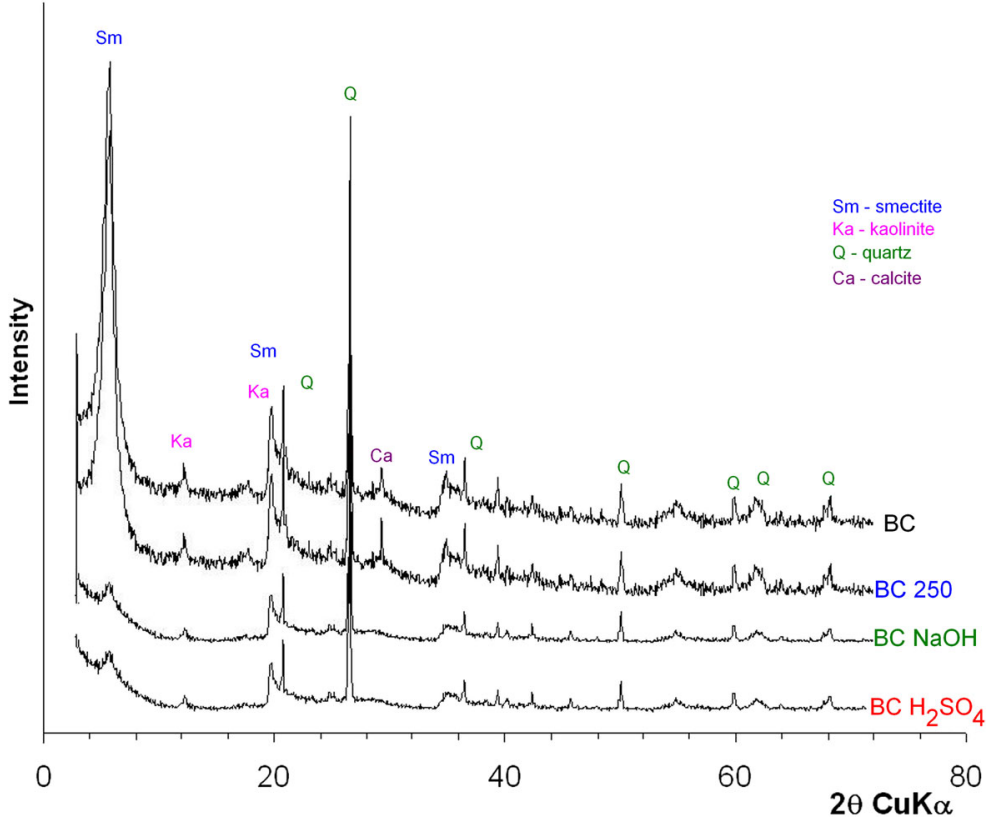


Table 1 Physicochemical properties and chemical composition (\%) of natural and modified clay

\begin{tabular}{lllll}
\hline & $\mathrm{BC}$ & $\mathrm{BC} 250$ & $\begin{array}{l}\mathrm{BC} \\
\mathrm{H}_{2} \mathrm{SO}_{4}\end{array}$ & $\begin{array}{l}\mathrm{BC} \\
\mathrm{NaOH}\end{array}$ \\
\hline $\mathrm{SiO}_{2}$ & 55.81 & 56.65 & 92.11 & 32.11 \\
$\mathrm{Al}_{2} \mathrm{O}_{3}$ & 15.25 & 16.57 & 5.34 & 40.17 \\
$\mathrm{Fe}_{2} \mathrm{O}_{3}$ & 6.45 & 7.65 & 0.3400 & 1.11 \\
$\mathrm{CaO}$ & 2.82 & 3.23 & 0.5600 & 2.23 \\
$\mathrm{MgO}$ & 1.74 & 2.32 & 0.6700 & 2.94 \\
$\mathrm{Na}_{2} \mathrm{O}$ & 0.04200 & 1.11 & 0.01001 & 20.63 \\
$\mathrm{~K}_{2} \mathrm{O}$ & 0.5700 & 3.32 & 0.2100 & 0.7800 \\
$\mathrm{SiO}$ & & & & \\
$\mathrm{SSA}_{2}\left(\mathrm{Al}_{2} \mathrm{O}_{3} / \mathrm{g}\right)$ & 3.66 & 3.42 & 17.25 & 0.8200 \\
$\mathrm{Porosity}(\%)_{\mathrm{Average} \mathrm{pore} \mathrm{diameter}}$ & 0.01860 & 0.03220 & 2.11 & 0.6362 \\
$\quad(\mu \mathrm{m})$ & 6.82 & 11.13 & 42.68 & 53.34 \\
$\mathrm{pH}$ & 7.95 & 7.83 & 3.39 & 10.28 \\
$\mathrm{pH}$ & 7.42 & 7.20 & 3.22 & 9.66 \\
\hline
\end{tabular}

substitution of the octahedral $\mathrm{Al}$ by $\mathrm{Fe}$; $-\mathrm{OH}$ groups, originating from the smectite and kaolinite minerals; and $-\mathrm{H}-\mathrm{O}-\mathrm{H}$ molecules of water adsorbed in the smectite minerals (Fig. 5).

The total SSA of the BC was $141.80 \mathrm{~m}^{2} / \mathrm{g}$, the porosity was $6.82 \%$, the average pore diameter was $0.01860 \mu \mathrm{m}$, and the $\mathrm{pH}$ value for natural clay was 7.95 , while the point of zero charge was 7.42 (Table 1).

Thermal modification of clay caused dehydration of smectite structures; moreover, only slight changes in the diffraction pattern were observed (Fig. 4), consisting in a shift of the peaks corresponding to the structure of smectite towards higher values of $2 \theta$. Structural changes caused by smectite dehydration can also be observed in the FT-IR spectra (Fig. 5) of the tested samples. The removal of water molecules as a result of heating the sample to $250{ }^{\circ} \mathrm{C}$ is reflected in the FT-IR spectra of BC clay as a reduction in the intensity of IR bands located at 3623 and $1654 \mathrm{~cm}^{-1}$, coming from $-\mathrm{OH}$ and $-\mathrm{H}-\mathrm{O}-\mathrm{H}$ groups. Slight changes were found in the chemical composition of BC 250, which mainly resulted from dehydration and dehydroxylation of hydrated minerals. Furthermore, thermal modification resulted in a $6.50 \%$ increase in the silica-to-alumina ratio. SSA increased by almost $6 \%$. The elimination of water molecules contributed to a significant increase in porosity (63\%), as well as an almost twofold increase in the average pore diameter. The values of $\mathrm{pH}$ and $\mathrm{pH}_{\mathrm{PZC}}$ decreased slightly, from 7.95 to 7.83 and from 7.42 to 7.20 , respectively (Table 1).

Based on the clay diffraction pattern analysis, it was observed that acid modification resulted in decrease and disappearance of the basic smectite peaks, as well as disappearance of the calcite peak (Fig. 4). On the basis of X-ray analysis of the clay sample, it was observed that acid modification caused a reduction in intensity and smoothing of the main smectite peaks, while the peaks attributed to kaolinite remained unchanged and the calcite peak disappeared. During modification of the clay samples with sulfuric acid, protons penetrated the
Fig. 5 FT-IR spectra of natural (BC) and thermally (BC 250), alkaline $(\mathrm{BC} \mathrm{NaOH})$ - and acid (BC $\mathrm{H}_{2} \mathrm{SO}_{4}$ )-modified clay samples

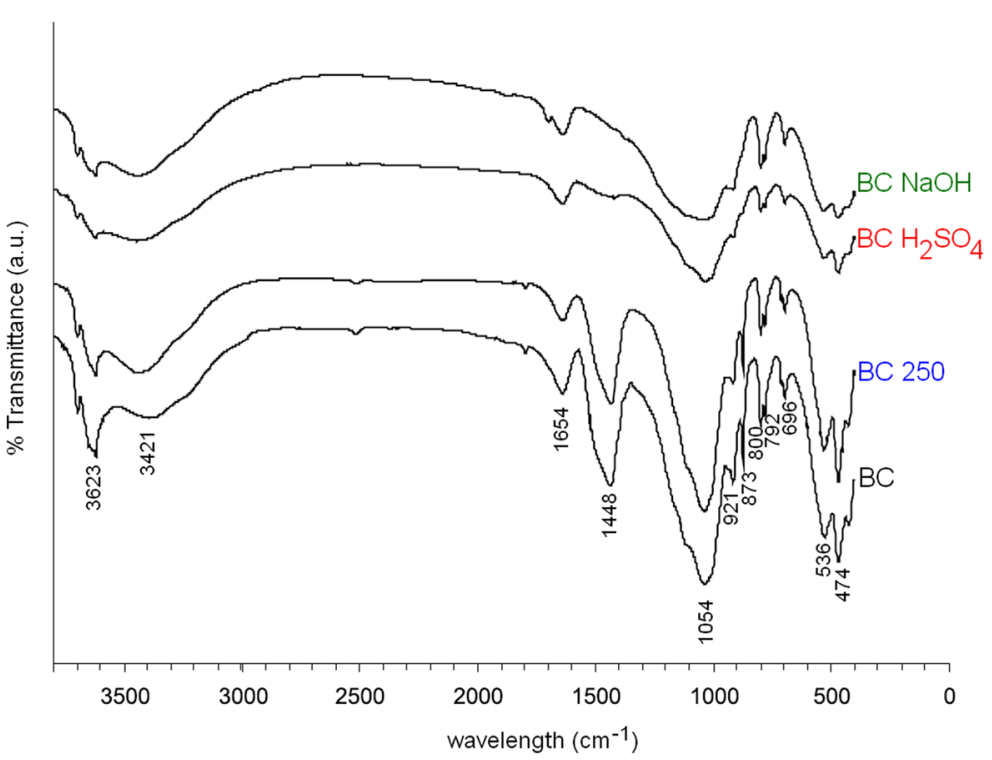


clay mineral layer and attacked the structural $-\mathrm{OH}$ groups. As a result of dehydroxylation, the octahedral layer was destroyed, which was also reflected in the FTIR spectra (Fig. 5). Destruction of the octahedral smectite sheets was additionally confirmed by complete disappearance of the peak intensity of the characteristic band at $873 \mathrm{~cm}^{-1}$, coming from-AlFe-OH groups, as well as a decrease in intensity at 921 and $536 \mathrm{~cm}^{-1}$, coming from $-\mathrm{Al}_{2}-\mathrm{OH}$ and $-\mathrm{AlFe}-\mathrm{OH}$ groups, respectively. Moreover, a decrease in the intensity of the vibrations centered at 1054 and $474 \mathrm{~cm}^{-1}$ was observed, coming from $-\mathrm{Si}-\mathrm{O}$ groups, related to degradation of the tetrahedral layers. Furthermore, the $1448 \mathrm{~cm}^{-1}$ peak from calcite disappeared as a result of chemical reactions: $\mathrm{CaCO}_{3}+\mathrm{H}_{2} \mathrm{SO}_{4} \rightarrow \mathrm{Ca}^{2+}+\mathrm{SO}_{4}{ }^{2-}+\mathrm{CO}_{2}+\mathrm{H}_{2} \mathrm{O}$.

The exchange of spent sulfuric acid during modification prevented the precipitation of $\mathrm{CaSO}_{4}$. As a result of acid leaching and dissolution of the octahedral layers, there was a significant increase in $\mathrm{SiO}_{2}$ content (65\%), as well as a decrease in $\mathrm{Al}_{2} \mathrm{O}_{3}$ by $65 \%$, thus contributing to a 4.7-fold increase in the silica to alumina ratio to 17.25. The remaining oxide content as a result of acid modification also decreased significantly $\left(\mathrm{Fe}_{2} \mathrm{O}_{3}\right.$ decreased by $95 \%, \mathrm{CaO}$ by $80 \%, \mathrm{MgO}$ by $61.50 \%$, $\mathrm{Na}_{2} \mathrm{O}$ by $76 \%$, and $\mathrm{K}_{2} \mathrm{O}$ decreased by $63 \%$ ) (Table 1 ). This modification resulted in a slight increase (about $1 \%$ ) in the SSA. In turn, the porosity increased 6.3-fold to $42.68 \%$, while the average pore diameter increased over 100 times to $2.11 \mu \mathrm{m}$. Saturation of the sorption complex with $\mathrm{H}^{+}$ions caused a noticeable decrease in $\mathrm{pH}$ to 3.39 , as well as in $\mathrm{pH}_{\mathrm{PZC}}$ to 3.22 . Similar observations were made by other researchers (Akpomie and Dawodu 2016) who conducted studies on sorption of heavy metals using modified montmorillonite. They observed that the acid modification of montmorillonite also caused an increase in porosity and decrease in $\mathrm{pH}$ and $\mathrm{pH}_{\mathrm{PZC}}$. Chaari et al. (2008), during laboratory studies on the removal of lead from aqueous solutions by smectitic clay, also observed that modification with $\mathrm{H}_{2} \mathrm{SO}_{4}$ acid improved the physicochemical properties of smectite clay compared to natural clay.

On the basis of diffractogram analysis, it was observed that alkaline modification of clay resulted in decrease and disappearance of basic smectite peaks as well as calcite peaks (Fig. 4). This is also confirmed by the FT-IR spectra (Fig. 5), where a decrease in intensity at 1054 and $476 \mathrm{~cm}^{-1}$, coming from vibrations of $-\mathrm{Si}-\mathrm{O}$ groups in the tetrahedral layer, was observed. Furthermore, the $1448 \mathrm{~cm}^{-1}$ peak from calcite disappeared as a result of chemical reactions: $\mathrm{CaCO}_{3}+2 \mathrm{NaOH} \rightarrow$ $\mathrm{Na}_{2} \mathrm{CO}_{3}+\mathrm{CaO} \downarrow+\mathrm{H}_{2} \mathrm{O}$.

The modification using $\mathrm{NaOH}$ resulted in a significant, almost 500-fold, increase in $\mathrm{Na}_{2} \mathrm{O}$ content. In addition, dissolution of the tetrahedral layers and free silica resulted in an increase in $\mathrm{Al}_{2} \mathrm{O}_{3}$ content of about $164 \%$ and a decrease in $\mathrm{SiO}_{2}$ by $42.50 \%$, thus contributing to a 4.5 -fold decrease in the silica to alumina ratio to 0.82 . The content of $\mathrm{Fe}_{2} \mathrm{O}_{3}$ and $\mathrm{CaO}$ oxides decreased by $83 \%$ and $21 \%$, respectively, while that of $\mathrm{MgO}$ and $\mathrm{K}_{2} \mathrm{O}$ oxides increased by $69 \%$ and $37 \%$, respectively. Moreover, there was a significant increase in the surface area $(51 \%)$ and a 7.8 -fold increase in porosity, as well as a 34-fold increase in the mean average pore diameter to $0.6362 \mu \mathrm{m}$. This modification also affected the $\mathrm{pH}$ and $\mathrm{pH}_{\text {PZC }}$ values, which increased to 10.28 and 9.66, respectively (Table 1). Soni et al. (2018) during their study found that the alkaline modification of clay also significantly increased the SSA and porosity of the studied clay, and also increased the $\mathrm{pH}$ and $\mathrm{pH}_{\mathrm{PZC}}$ values.

\subsection{Adsorption of RR 198 and AR 18 Dyes onto Natural and Modified Clay}

The adsorption capacity $(q)$ was plotted as a function of the equilibrium concentration $\left(C_{\text {eq }}\right)$, and removal efficiency (RE) - which shows the percentage of RR 198 and AR 18 dyes adsorbed from aqueous solutions - as function of initial concentration $\left(C_{0}\right)$ (Figs. 6 and 7).

It was observed that the adsorption capacity of clay depended on the initial concentration of dye in the solution, the type of dye, and the kind of clay modification.

The results show that all the modifications of the clay increased its adsorption capacity in relation to the reactive dyes (Fig. 6). At the maximum initial concentration of $1000 \mathrm{mg} / \mathrm{dm}^{3}, 2.91 \mathrm{mg} / \mathrm{g}$ (RE 14.78\%) of RR 198 dye was bound by BC; $16.79 \%$ more RR 198 dye was bound by BC 250 than by BC, i.e., a maximum of 3.32 $\mathrm{mg} / \mathrm{g}$ (RE $16.79 \%$ ); and $73.20 \%$ more of the dye was removed by $\mathrm{BC}_{2} \mathrm{SO}_{4}$ than by $\mathrm{BC}$, i.e., $5.06 \mathrm{mg} / \mathrm{g}$ at the maximum initial concentration ( $\mathrm{RE} 25.22 \%$ ). The largest amount of RR 198 dye was removed by BC $\mathrm{H}_{2} \mathrm{SO}_{4}, 10.32 \mathrm{mg} / \mathrm{g}$ at a maximum initial dye concentration of $1000 \mathrm{mg} / \mathrm{dm}^{3}$ (RE 51.40\%). $\mathrm{BC}_{2} \mathrm{SO}_{4}$ bound $253 \%$ more of the reactive dye than $\mathrm{BC}$.

Smaller amounts of AR 18 dye than RR 198 dye were removed by both natural and modified clay: 2.16 $\mathrm{mg} / \mathrm{g}$ (RE $10.56 \%$ ) of AR 18 dye was bound at a 

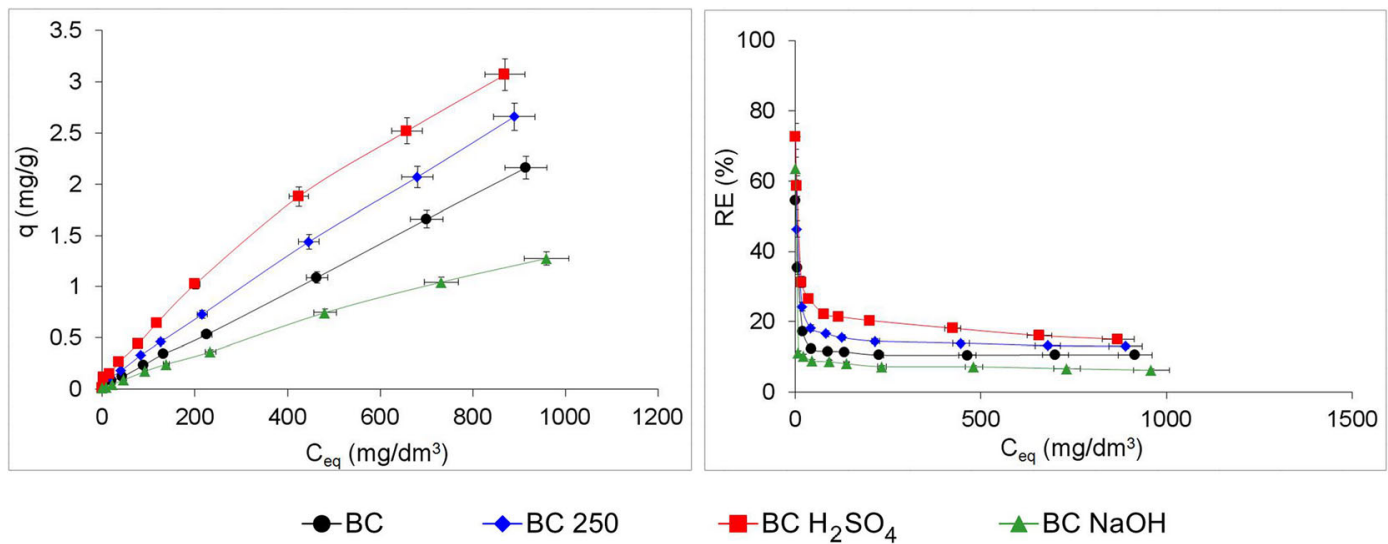

Fig. 6 Equilibrium adsorption isotherms and removal efficiency of RR 198 onto natural and modified clays

maximum initial concentration of $1000 \mathrm{mg} / \mathrm{dm}^{3}$; $23.15 \%$ more of this dye was bound by $\mathrm{BC} 250$ than by $\mathrm{BC}$, i.e., a maximum of $2.66 \mathrm{mg} / \mathrm{g}$ (RE $13 \%)$. As observed for RR 198, the largest amounts of AR 18 dye were removed by $\mathrm{BC}_{2} \mathrm{SO}_{4} ; 42.13 \%$ more of the dye was bound by $\mathrm{BC}_{2} \mathrm{SO}_{4}$ than by $\mathrm{BC}$, i.e., a maximum of $3.07 \mathrm{mg} / \mathrm{g}$ (RE 15.01\%). In contrast, $\mathrm{BC} \mathrm{NaOH}$ bound $40.74 \%$ less AR 18 dye, i.e., a maximum of $1.28 \mathrm{mg} / \mathrm{g}$ (RE 6.24\%) (Fig. 7).

Dependence of the $\mathrm{pH}$ values of the equilibrium solutions and the type of adsorbent modification used was observed (Fig. 8). The adsorption of RR 198 and AR 18 from aqueous solutions onto $\mathrm{BC}$ occurred at $\mathrm{pH}$ in the range of 8.11-8.29 and 8.02-8.17, respectively, i.e., at a $\mathrm{pH}$ close that of the BC. Adsorption of dyes onto $\mathrm{BC} 250$ was carried out at similar $\mathrm{pH}$ values, i.e., for dye RR 198 in the range of 8.19-8.30 and for dye AR 18 in the range of 8.13-8.24. Adsorption of the dyes

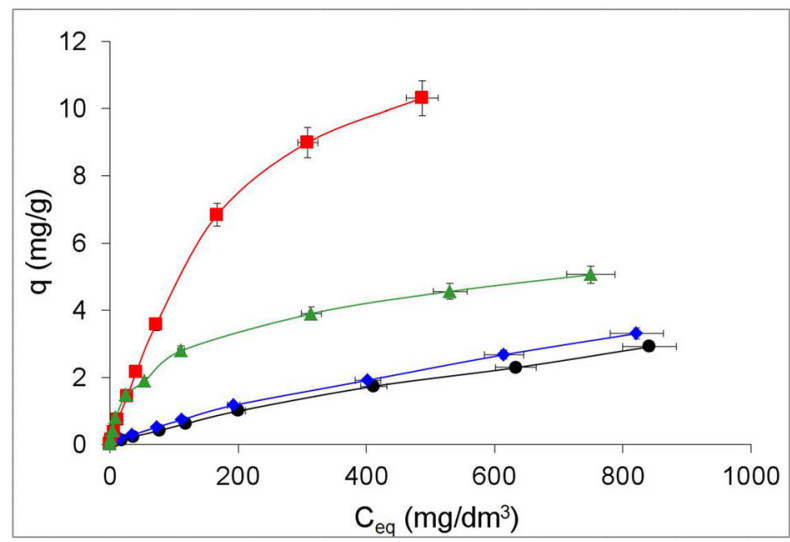

$\mathrm{BC}$

BC 250 by $\mathrm{BC} \mathrm{H}_{2} \mathrm{SO}_{4}$ was carried out at $\mathrm{pH}$ in the range of 3.46-3.95 for dye RR 198 and 3.75-4.15 for AR 18. These values were also close to the $\mathrm{pH}$ values of the clay after modification with acid $\mathrm{H}_{2} \mathrm{SO}_{4}$. However, the process of adsorption of RR 198 and AR 18 onto clay modified with $\mathrm{NaOH}$ solution was carried out at $\mathrm{pH}$ values in the range of $7.68-8.23$ and $7.89-8.01$, respectively.

It was observed that the adsorption of RR 198 and AR 18 dyes onto $\mathrm{BC}, \mathrm{BC} 250$, and $\mathrm{BC}_{2} \mathrm{SO}_{4}$ occurred at a $\mathrm{pH}$ higher than the adsorbent's point of zero charge (Fig. 8), which means that the surface of the clay during adsorption of the dyes was negatively charged, according to the reaction: $\mathrm{AOH} \leftrightarrow \mathrm{AO}^{-}+\mathrm{H}^{+}$(where $\mathrm{A}$ is $\mathrm{Si}$ or Al). RR 198 and AR 18 are anionic dyes and cannot be bound due to electrostatic interactions in these cases. To explain the mechanisms of adsorption, it is necessary to take into account the surface structure of the adsorbent

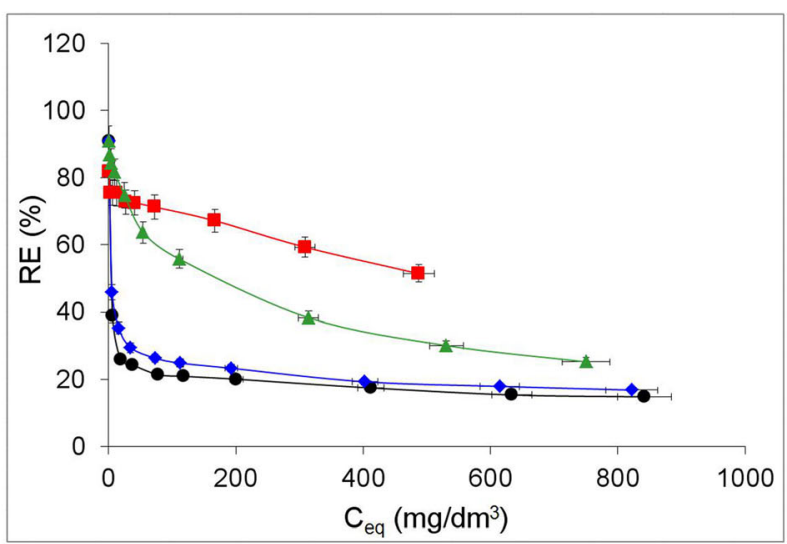

$\mathrm{BC} \mathrm{H}_{2} \mathrm{SO}_{4}$ $-\mathrm{BC} \mathrm{NaOH}$

Fig. 7 Equilibrium adsorption isotherms and removal efficiency of AR 18 onto natural and modified clays 

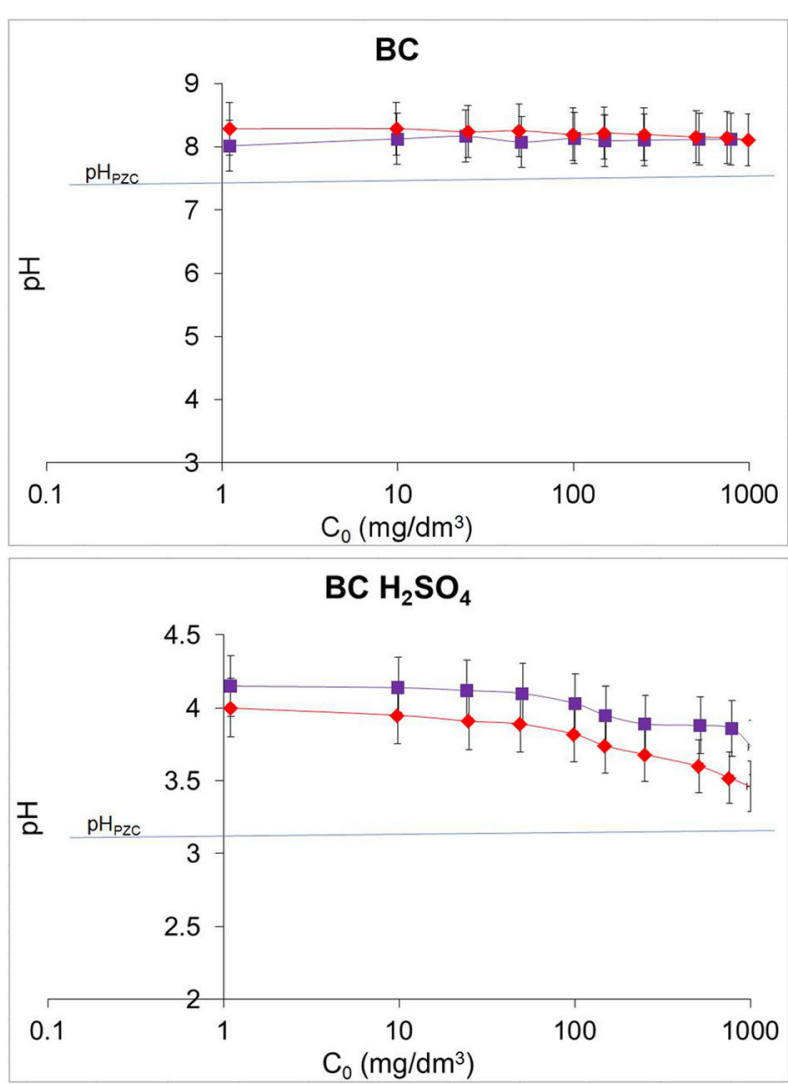

RR 198

Fig. 8 pH values in equilibrium solutions for RR 198 and AR 18

with various functional groups, and the structure of the dyes, and the amount of hydrogen atom donors and hydrogen atom acceptors they have should also be considered. On the surface of the adsorbents, depending on the type of clay (natural or modified), there are areas rich in silica or alumina with $-\mathrm{OH}$ and $-\mathrm{OH}_{2}^{+}$groups and oxygen bridges depending on the $\mathrm{pH}$ of the solution. Taking into account the structure of the dyes RR 198 and AR 18 as well as the structure of BC, BC 250, and $\mathrm{BC} \mathrm{H}_{2} \mathrm{SO}_{4}$, it can be concluded that the dyes were probably bound through chemisorption by forming hydrogen bonds between the $-\mathrm{Si}-\mathrm{OH}$ and $-\mathrm{Al}-\mathrm{OH}$ groups in the clay and the $-\mathrm{NH},-\mathrm{NH}_{2}$, and $-\mathrm{OH}$ groups in the dyes. Moreover, it was observed that with an increase in the number of donor groups, e.g., $-\mathrm{OH},=\mathrm{NH}$, and $-\mathrm{NH}_{2}$ in the dye molecule, the amount of dye bound by clay increased.

In turn, the adsorption of anionic dyes onto $\mathrm{BC}$ $\mathrm{NaOH}$ occurred at a $\mathrm{pH}$ below the adsorbent's point of zero charge, which means that the surface of the clay
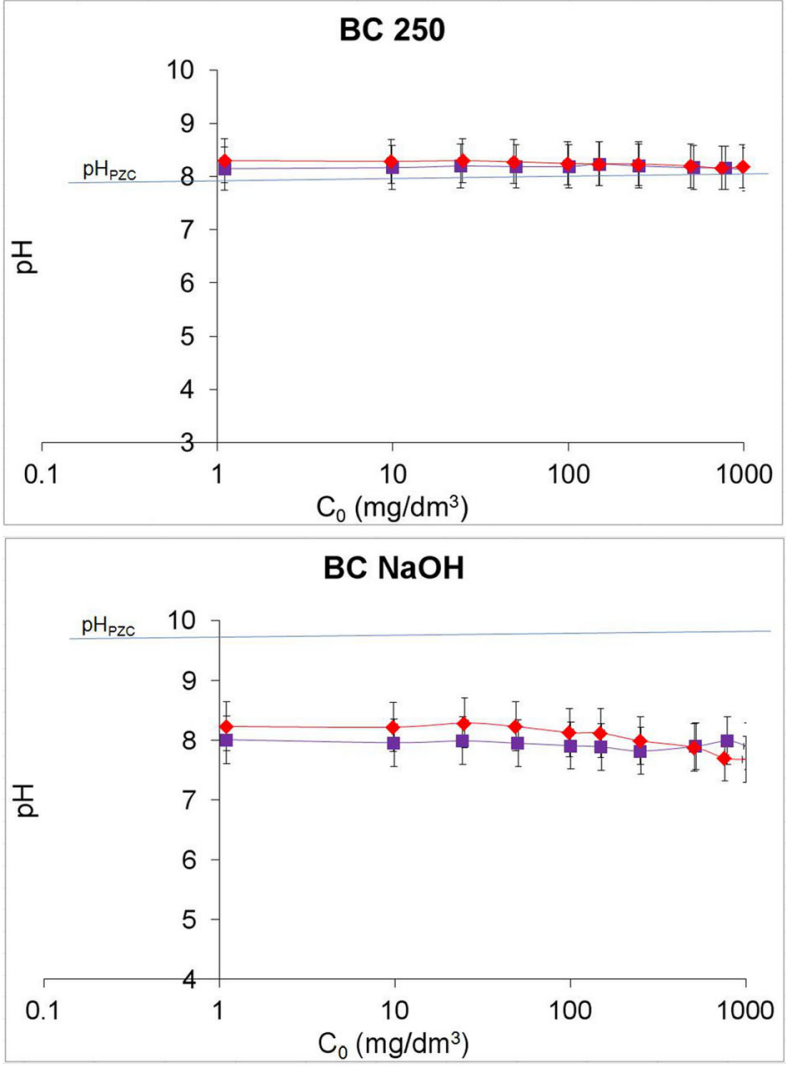

AR 18

during adsorption of the dyes was positively charged, according to the reaction: $\mathrm{AOH}_{2}{ }^{+} \leftrightarrow \mathrm{AOH}+\mathrm{H}^{+}$(where $\mathrm{A}$ is $\mathrm{Si}$ or $\mathrm{Al}$ ), which may suggest the possibility of electrostatic interactions. However, taking into account the fact that the smallest quantities of both anionic dyes were removed by $\mathrm{BC} \mathrm{NaOH}$, it can be assumed that these interactions had a negligible effect on the amount of dye bound. These results are consistent with other studies showing that the structure of anionic dyes and structure of adsorbents rich in silica and aluminum oxides play a significant role in adsorption of anionic dyes and in determining the binding mechanism of anionic dyes. Wawrzkiewicz et al. (2015) in their work on adsorption of acid, reactive, and direct dyes from aqueous solutions and wastewater using mixed silicaalumina oxide came to a similar conclusion. Similar observations were made by Anbia and Salehi (2012) during their research on the removal of acid dyes from aqueous media by adsorption onto amino-functionalized nanoporous silica, as well as by Krysztafkiewicz et al. 
(2002) in their studies on the adsorption of dyes onto a silica surface.

The highest maximum adsorption capacity of the natural and modified clay in relation to RR 18 and AR 198 from aqueous solution is shown in Fig. 9.

According to the results obtained, it was observed that RR 198 dye was bound in noticeably larger amounts than AR 18 dye, i.e., $6.02 \%, 24.81 \%$, $236.16 \%$, and $295.31 \%$ larger by $\mathrm{BC}, \mathrm{BC} 250, \mathrm{BC}$ $\mathrm{H}_{2} \mathrm{SO}_{4}$, and $\mathrm{BC} \mathrm{NaOH}$, respectively. In addition, it is seen that acid activation significantly increased the adsorption capacity for the anionic dyes tested. Significant differences in the amount of anionic dyes bound to the tested adsorbents most likely result from the dye structure and the difference between the hydrogen atom donors and the hydrogen atoms acceptors in the dyes, as well as from the surface structure of the adsorbent with different functional groups, which differ depending on the modification applied. Moreover, it has been observed that there is a relationship between maximum adsorption capacity and average pore diameter. As the pore size increases, depending on the clay modification used, the maximum adsorption capacity of both anionic dyes increases. Gil et al. (2013), during studies on adsorption of methylene blue on thermally and acid-activated clay minerals, found that the acid activation of clay, such as montmorillonite, significantly increases the adsorption capacity for anionic dye. Similar results were obtained by Akpomie et al. (2017) who carried out adsorption studies of anionic dye onto acid-activated montmorillonite.

\subsection{Adsorption Isotherms}

The parameters estimated from the Freundlich, Langmuir, Dubinin-Radushkevich, and Sips models using nonlinear regression analysis, the determination coefficient $\left(R^{2}\right)$, and the error functions (SSE, RMSE, and $\chi^{2}$ ) are presented in Table 2. On the basis of the determination coefficient $\left(R^{2}<0.9000\right)$ and the lowest values of the error function, it can be seen that the models of isotherms used, i.e., Freundlich, Langmuir, Dubinin-Radushkevich, and Sips, demonstrated good quality of fitting of the isotherm equations to the experimental data.

The values of the parameter $1 / n_{\mathrm{F}}$ estimated from the Freundlich isotherm for all clay-dye systems, except in one case, were lower than 1 . If the value of $1 / n_{\mathrm{F}}$ is smaller than 1 , reflecting favorable adsorption, then the sorption capacity increases and new adsorption sites occur (Özcan et al. 2004). Bendaho et al. (2017), in research on the adsorption of acid dye onto activated clay, obtained similar results; namely, on the basis of the value of the parameter $1 / n_{\mathrm{F}}$, they found that the adsorption of methyl orange onto clay also has a favorable nature, as did Arellano-Cárdenas et al. (2013) who carried out adsorption studies of malachite green onto organically modified clay. The value of the parameter $1 / n_{\mathrm{F}}$ for adsorption of AR 18 dye onto alkaline-modified clay was above 1 , which indicates the unfavorable nature of the adsorption process, which also resulted in the lowest adsorption capacity of the alkaline-modified clay in relation to this dye (Fig. 7). Similar results were obtained by Özcan et al. (2004) who carried out
Fig. 9 Comparison of maximum adsorption capacities of natural and modified clay for anionic dyes

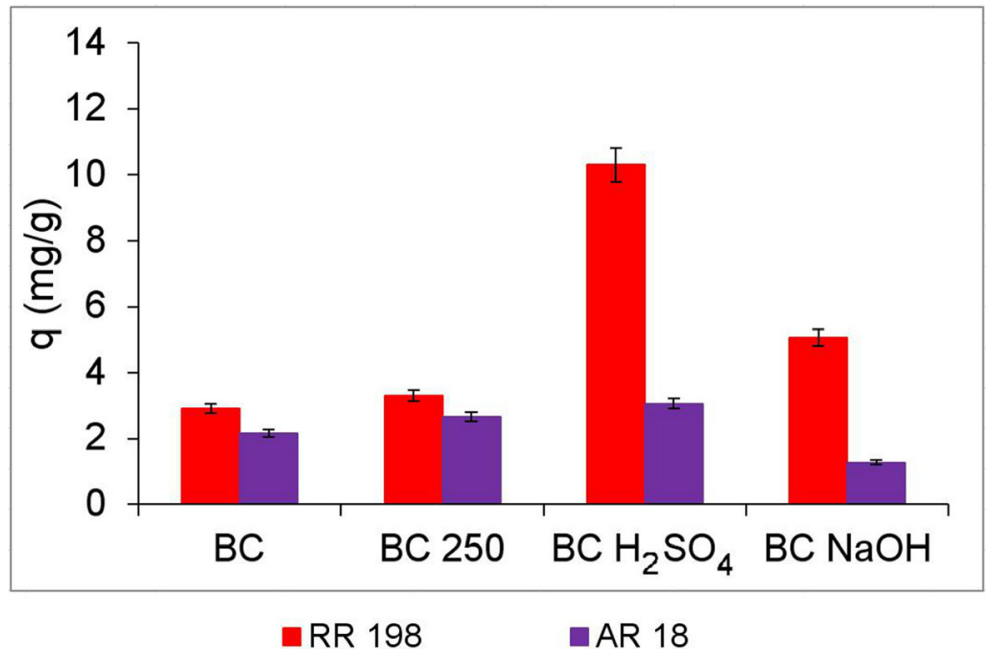


Table 2 Isotherm parameters and error functions data

\begin{tabular}{|c|c|c|c|c|c|c|c|c|}
\hline & \multicolumn{4}{|l|}{ AR 18} & \multicolumn{4}{|l|}{ RR 198} \\
\hline & $\mathrm{BC}$ & BC 250 & $\mathrm{BC} \mathrm{H}_{2} \mathrm{SO}_{4}$ & $\mathrm{BC} \mathrm{NaOH}$ & $\mathrm{BC}$ & BC 250 & $\mathrm{BC} \mathrm{H}_{2} \mathrm{SO}_{4}$ & $\mathrm{BC} \mathrm{NaOH}$ \\
\hline \multicolumn{9}{|l|}{ Freundlich isotherm } \\
\hline $1 / n_{\mathrm{F}}$ & 0.7919 & 0.7365 & 0.5879 & 0.3895 & 0.9576 & 0.9246 & 0.7591 & 1.01 \\
\hline$K_{\mathrm{F}}\left(\mathrm{mg} / \mathrm{g}(\mathrm{L} / \mathrm{mg})^{1 / \mathrm{nF}}\right)$ & 0.01413 & 0.02363 & 0.2922 & 0.3981 & 0.003130 & 0.004993 & 0.01823 & 0.001338 \\
\hline$R^{2}$ & 0.9978 & 0.9995 & 0.9717 & 0.9892 & 0.9984 & 0.9982 & 0.9985 & 0.9912 \\
\hline SSE & 0.02150 & 0.006120 & 3.85 & 0.3418 & 0.007923 & 0.01452 & 0.01601 & 0.01774 \\
\hline RMSE & 0.04637 & 0.02474 & 0.6208 & 0.1849 & 0.02815 & 0.03810 & 0.04001 & 0.04212 \\
\hline$\chi^{2}$ & 0.1763 & 0.06685 & 1.62 & 0.4650 & 0.2347 & 0.3728 & 0.09704 & 0.4161 \\
\hline \multicolumn{9}{|l|}{ Langmuir isotherm } \\
\hline$q_{\exp }(\mathrm{mg} / \mathrm{g})$ & 2.92 & 3.32 & 10.32 & 5.06 & 2.16 & 2.66 & 3.07 & 1.28 \\
\hline$q_{\max }(\mathrm{mg} / \mathrm{g})$ & 7.79 & 7.47 & 14.79 & 5.35 & 45.02 & 20.30 & 7.36 & 20.59 \\
\hline$K_{\mathrm{L}}(\mathrm{L} / \mathrm{mg})$ & 0.0006944 & 0.0009353 & 0.005006 & 0.01115 & 0.00005480 & 0.0001688 & 0.0008107 & 0.00007072 \\
\hline$R_{\mathrm{L}}$ & 0.9980 & 0.9969 & 0.9509 & 0.9466 & 0.9999 & 0.9995 & 0.9975 & 0.9999 \\
\hline$R^{2}$ & 0.9982 & 0.9960 & 0.9962 & 0.9863 & 0.9981 & 0.9981 & 0.9984 & 0.9916 \\
\hline SSE & 0.01722 & 0.04881 & 0.5095 & 0.4309 & 0.009569 & 0.01531 & 0.01673 & 0.01692 \\
\hline RMSE & 0.04150 & 0.06987 & 0.2257 & 0.2076 & 0.03093 & 0.03913 & 0.04090 & 0.04114 \\
\hline$\chi^{2}$ & 0.7804 & 0.7048 & 0.2366 & 0.6550 & 0.3201 & 0.5896 & 0.5011 & 0.3893 \\
\hline \multicolumn{9}{|c|}{ Dubinin-Radushkevich isotherm } \\
\hline$\beta\left(\mathrm{mol}^{2} / \mathrm{kJ}^{2}\right)$ & 0.008141 & 0.007485 & 0.005437 & 0.003552 & 0.01086 & 0.01042 & 0.008338 & 0.01152 \\
\hline$q_{\mathrm{D}}(\mathrm{mmol} / \mathrm{g})$ & 0.00003441 & 0.00003235 & 0.00007503 & 0.00001579 & 0.00005612 & 0.00006387 & 0.00004408 & 0.00003943 \\
\hline$E(\mathrm{~kJ} / \mathrm{mol})$ & 7.94 & 8.17 & 9.59 & 11.86 & 6.79 & 6.93 & 7.74 & 6.59 \\
\hline$R^{2}$ & 0.9984 & 0.9981 & 0.9828 & 0.9972 & 0.9959 & 0.9971 & 0.9986 & 0.9944 \\
\hline SSE & 0.01498 & 0.02262 & 2.34 & 0.08931 & 0.02077 & 0.02289 & 0.01539 & 0.01116 \\
\hline RMSE & 0.03870 & 0.04756 & 0.4840 & 0.09450 & 0.04557 & 0.04785 & 0.03924 & 0.03341 \\
\hline$\chi^{2}$ & 4.29 & 1.66 & 0.8921 & 0.1398 & 2.48 & 5.10 & 0.8383 & 11.36 \\
\hline \multicolumn{9}{|l|}{ Sips isotherm } \\
\hline$q_{\max }(\mathrm{mg} / \mathrm{g})$ & 11.38 & 14.77 & 12.13 & 7.83 & 10.95 & 11.08 & 13.19 & 2.84 \\
\hline$K_{\mathrm{S}}\left((\mathrm{L} / \mathrm{mg})^{1 / \mathrm{nS}}\right)$ & 0.0007054 & 0.001019 & 0.002177 & 0.02796 & 0.0002092 & 0.0003094 & 0.0008423 & 0.0001753 \\
\hline $1 / n_{\mathrm{S}}$ & 0.9174 & 0.8359 & 1.26 & 0.6266 & 1.03 & 1.01 & 0.8698 & 1.23 \\
\hline$R^{2}$ & 0.9984 & 0.9992 & 0.9992 & 0.9984 & 0.9991 & 0.9986 & 0.9991 & 0.9977 \\
\hline SSE & 0.01486 & 0.02206 & 0.1024 & 0.04901 & 0.01647 & 0.02452 & 0.01014 & 0.01173 \\
\hline RMSE & 0.03855 & 0.04696 & 0.1012 & 0.07001 & 0.04058 & 0.04951 & 0.03184 & 0.03426 \\
\hline$\chi^{2}$ & 0.01697 & 0.02073 & 0.06286 & 0.02711 & 0.03837 & 0.06979 & 0.009294 & 0.04748 \\
\hline
\end{tabular}

adsorption studies of Acid Blue 193 from aqueous solutions onto bentonites.

A higher intensity was observed for the adsorption of RR 198 dye $\left(K_{\mathrm{F}}\right)$ onto $\mathrm{BC}_{2} \mathrm{SO}_{4}$ and $\mathrm{BC} \mathrm{NaOH}$, which is reflected in the experimental results obtained shown in Fig. 10.

Useful information, such as the maximum adsorption capacity $\left(q_{\max }\right)$ and isothermal constant $\left(K_{\mathrm{L}}\right)$, which is associated with binding site affinity and binding energy, is provided by the Langmuir isotherm. The values of the $q_{\max }$ parameter for all investigated dye-adsorbent systems were greater than the experimental values, which may indicate incomplete covering of the monolayer. The calculated value of the $K_{\mathrm{L}}$ parameter, related to the adsorption energy of the dyes, was in the range of $0.01115-0.0006944$ and $0.0001688-0.00005480 \mathrm{dm}^{3} /$ $\mathrm{mg}$ for RR 198 and AR 18, respectively. This indicates a higher affinity of RR 198 to the surface of natural and 
RR 198

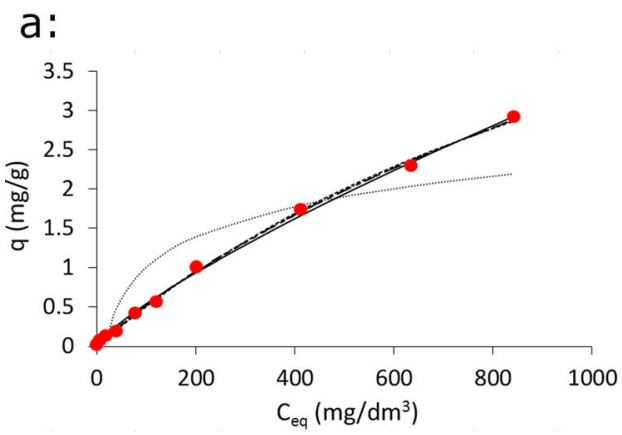

b:

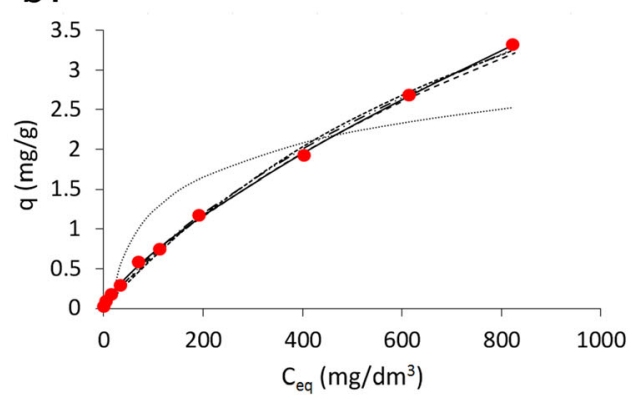

C:

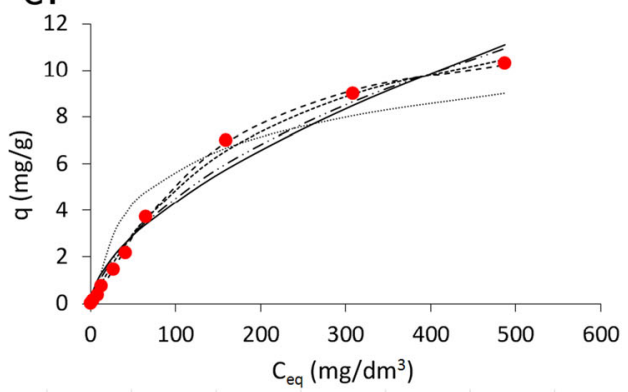

d:

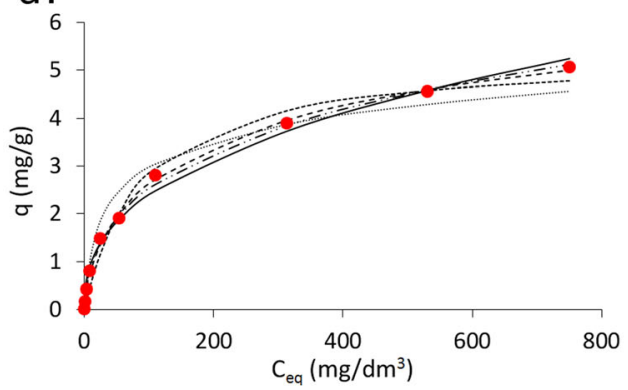

AR 18
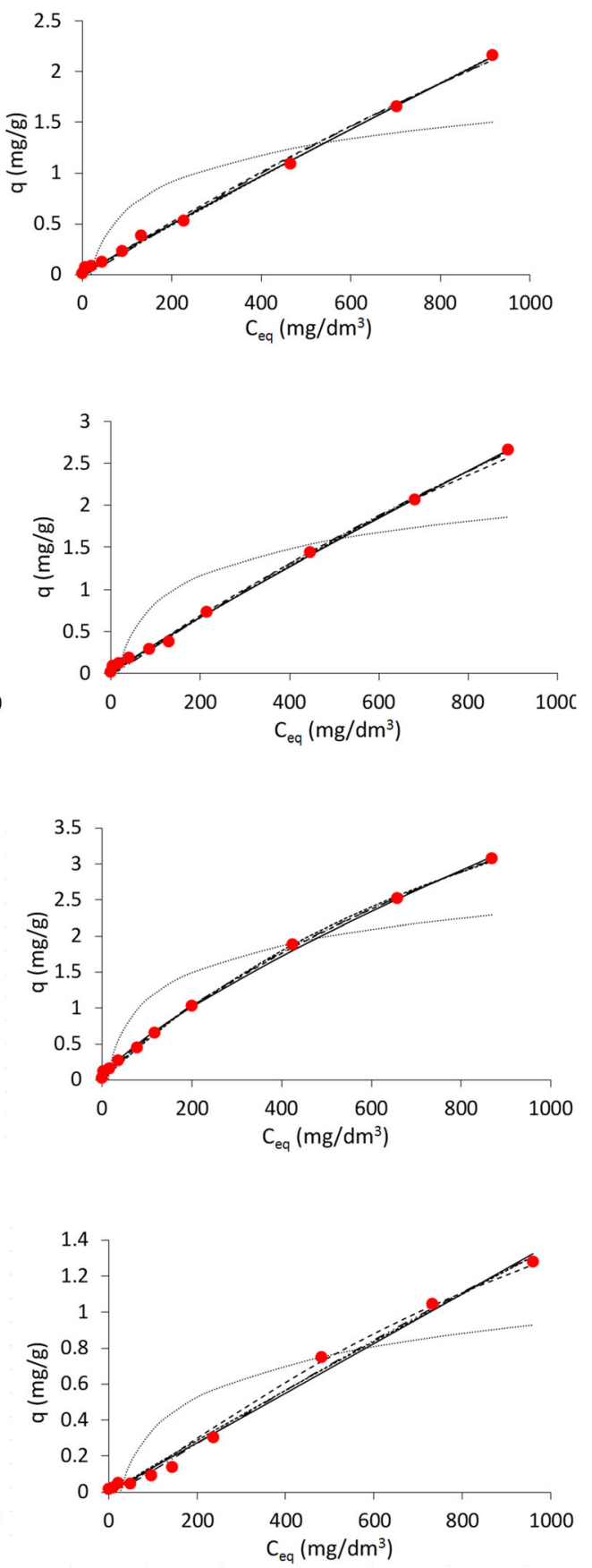

- q experimental isotherm

\section{-.--- q Langmuir isotherm}

\section{-..-- q Sips isotherm}

- $\mathrm{q}$ Freundlich isotherm

-..- q Dubinin-Radushkevich isotherm

Fig. 10 Comparison of experimental data with the adsorption isotherms of RR 198 and AR 18 onto natural and modified clay ((a) BC, (b) BC 250, (c) $\mathrm{BC} \mathrm{H}_{2} \mathrm{SO}_{4}$, (d) $\mathrm{BC} \mathrm{NaOH)}$ 
modified clays and a low energy of dye binding by clays. These assumptions were confirmed by the studies of other researchers, e.g., in tests on the adsorption of acid dyes from aqueous media onto aminofunctionalized nanoporous silica carried out by Anbia and Salehi (2012), as well as by the studies carried out by Wawrzkiewicz et al. (2015) on the adsorption of acid, reactive, and direct dyes from aqueous solutions and wastewater onto mixed silica-alumina oxide. The Langmuir constant $\left(K_{\mathrm{L}}\right)$ was lowest for the adsorption of AR 18 dye onto $\mathrm{BC} \mathrm{NaOH}$, indicating lower affinity of the dye for the $\mathrm{BC} \mathrm{NaOH}$ surface. The calculated parameter values are reflected in the experimental results presented in Fig. 6. Moreover, the values of the parameter $R_{\mathrm{L}}$ were below 1, indicating that the adsorption process is favorable for all dye-clay systems. Values of the parameter $R_{\mathrm{L}}$ less than 1 were also obtained by Gamoudi and Srasra (2019) studying the adsorption of organic dyes by modified clay, as well as by Chang et al. (2016) investigating the adsorption of methylene blue onto $\mathrm{Fe}_{3} \mathrm{O}_{4}$ /activated montmorillonite nanocomposite.

The values of the parameter $E$, which were calculated from the Dubinin-Radushkevich equation, were above $8 \mathrm{~kJ} / \mathrm{mol}$ for the adsorption of RR 198 dye onto BC 250 , $\mathrm{BC}_{2} \mathrm{SO}_{4}$, and $\mathrm{BC} \mathrm{NaOH}$, indicating that the adsorption is a chemical process. For the adsorption of RR 198 onto $\mathrm{BC}$, as well as the adsorption of AR 18 onto $\mathrm{BC}$ and modified clay, the values of the parameter $E$ were below $8 \mathrm{~kJ} / \mathrm{mol}$, indicating the physical nature of the process. Genc and Oguz (2010) obtained similar results during sorption studies of acid dyes from aqueous solution using non-ground ash and slag. They noticed that the magnitude of the constant in the DubininRadushkevich isotherm $(E)$ was very small, indicating that the adsorption energy is very low. Values of the parameter $E$ less than $8 \mathrm{~kJ} / \mathrm{mol}$ were also obtained by Chicinas et al. (2018) during research on the ability of a montmorillonitic clay to interact with cationic and anionic dyes in aqueous solutions.

When the $1 / n_{\mathrm{S}}$ parameter estimated from the Sips model, representing surface inhomogeneity, deviates from unity, then it indicates a heterogeneous surface. Moreover, the values of the $1 / n_{\mathrm{S}}$ parameter for all tested adsorbent-adsorbate systems were higher than the values of the $1 / n_{\mathrm{F}}$ parameter, calculated from the Freundlich isotherm, which additionally suggests the heterogeneity of the surface of the adsorbent. Hokkanen et al. (2018), as well as Dzieniszewska et al. (2019) and Saruchi Kumar (2019), presented similar assumptions in their research. As it is known, the Sips isotherm is a combination of the Langmuir and Freundlich equations, so it can be concluded that the mechanism of binding anionic dyes by natural and modified clay does not follow ideal monolayer adsorption. Therefore, it should be assumed that the binding mechanism of the tested dyes is more complex. Moreover, the adsorption capacity calculated from the Sips equation is more realistic than that calculated from Freundlich or Langmuir equations and indicates that different adsorption centers participate in dye uptake.

On the basis of the parameters estimated using nonlinear regression, the theoretical isotherms were plotted and are presented together with the experimental data in Fig. 8. It was found that the Sips isotherm best describes the experimental data over the whole range of the initial concentrations of both anionic dyes. Also, the values of the determination coefficient $R^{2}$ and analysis of the error functions SSE, RMSE, and $\chi^{2}$ (Table 2) indicate that the applied three-parameter Sips isotherm is the model which best fits the adsorption process, among the five isothermal models used.

\section{Conclusions}

The present research shows that smectite clay from the lignite deposit "Belchatow" (BC), obtained from the Belchatow Brown Coal Mine in Central Poland, can be used as a cheap, effective, and easily available alternative to expensive commercial activated carbon to remove acid dyes from an aqueous solution. Moreover, it was found that modifications of the clay (i.e., thermal, acidic, and alkaline) influenced its physicochemical properties, chemical composition, and, what is more, its adsorption capacity in relation to two anionic dyes. Thermal modification mainly influenced the increase in total SSA and porosity, while the chemical modifications influenced the changes in total SSA and porosity, as well as in the chemical composition, which was reflected in changes of $\mathrm{pH}$ and $\mathrm{pH}_{\mathrm{PZC}}$. It was observed that the dye RR 198 was bound in noticeably larger amounts than the dye AR 18 , by both natural clay and modified clay, i.e., $6.02 \%, 24.81 \%, 236.2 \%$, and $295.3 \%$ more onto $\mathrm{BC}, \mathrm{BC} 250, \mathrm{BC}_{2} \mathrm{SO}_{4}$, and $\mathrm{BC}$ $\mathrm{NaOH}$, respectively. Moreover, all modifications applied to the clay increased its adsorption capacity in relation to RR 198, while the acidic and thermal modification of clay increased its adsorption capacity in 
relation to AR 18. The highest amounts of both anionic dyes were removed by $\mathrm{BC}_{2} \mathrm{SO}_{4}$, i.e., a maximum of 10.32 and $3.07 \mathrm{mg} / \mathrm{g}$ for RR 198 and AR 18, respectively. Taking into account the values of the determination coefficient and the lowest values of the error function, it was found that the best quality of the isotherm equation fit to the experimental data was demonstrated by the Sips isotherm model over the whole range of the initial concentrations of both anionic dyes. Based on the structure of the dyes RR 198 and AR 18, the number of donor groups, e.g., $-\mathrm{OH},=\mathrm{NH}$ and $-\mathrm{NH}_{2}$ in the dye molecules, and the structure of $\mathrm{BC}, \mathrm{BC} 250$, and $\mathrm{BC}$ $\mathrm{H}_{2} \mathrm{SO}_{4}$, it can be assumed that the dyes were most likely bound by chemisorption by forming hydrogen bonds between the $-\mathrm{Si}-\mathrm{OH}$ and $-\mathrm{Al}-\mathrm{OH}$ groups in the clay and the $-\mathrm{NH},-\mathrm{NH}_{2}$, and $-\mathrm{OH}$ groups in the dyes. However, taking into account the calculated parameters of adsorption isotherms and fitting of isothermal models, it should be assumed that the binding mechanism of the tested dyes is a more complex process. The research results obtained here suggest the direction of using smectite clay as an effective adsorbent for treatment of wastewater from the textile industry.

Supplementary Information The online version contains supplementary material available at https://doi.org/10.1007/s11270021-05032-3.

Acknowledgements The study was conducted under the research statute of the Institute of Environmental Engineering of the Polish Academy of Sciences.

Open Access This article is licensed under a Creative Commons Attribution 4.0 International License, which permits use, sharing, adaptation, distribution and reproduction in any medium or format, as long as you give appropriate credit to the original author(s) and the source, provide a link to the Creative Commons licence, and indicate if changes were made. The images or other third party material in this article are included in the article's Creative Commons licence, unless indicated otherwise in a credit line to the material. If material is not included in the article's Creative Commons licence and your intended use is not permitted by statutory regulation or exceeds the permitted use, you will need to obtain permission directly from the copyright holder. To view a copy of this licence, visit http://creativecommons.org/licenses/by/4.0/.

\section{References}

Adeyemo, A. A., Adeoye, I. O., \& Bello, O. S. (2017). Adsorption of dyes using different types of clay: a review. Applied Water
Science, 7, 543-568. https://doi.org/10.1007/s13201-0150322-y.

Aguiar, J. E., Cecilia, J. A., Tavares, P. A. S., Azevedo, D. C. S., Rodríguez Castellón, E., Lucena, S. M. P., \& Silva Junior, I. J. (2017). Adsorption study of reactive dyes onto porous clay heterostructures. Applied Clay Science, 135, 35-44. https://doi.org/10.1016/j.clay.2016.09.001.

Akpomie, K. G., \& Dawodu, F. A. (2016). Acid-modified montmorillonite for sorption of heavy metals from automobile effluent. Beni-Suef University Journal of Basic and Applied Sciences, 5, 1-12. https://doi.org/10.1016/j. bjbas.2016.01.003.

Akpomie, K. G., Onoabedje, E. A., Alumona, T. N., Alum, O. L., Okagu, O. D., \& Ezeofor, C. C. (2017). Attenuation of methylene blue from aqua-media on acid activated montmorillonite of Nigerian origin. Journal of Environmental Science and Management, 20, 17-27.

Aksakal, O., \& Ucun, H. (2010). Equilibrium, kinetic and thermodynamic studies of the biosorption of textile dye (Reactive Red 195) onto Pinus sylvestris L. Journal of Hazardous Materials, 181, 666-672. https://doi.org/10.1016/j. jhazmat.2010.05.064.

Amaral, C. N. R., Feiteira, F. N., Cruz, R. C., Cravo, V. O., Cassella, R. J., \& Pacheco, W. F. (2016). Removal of basic violet 3 dye from aqueous media using a steel industry residue as solid phase. Journal of Environmental Chemical Engineering, 4, 4184-4193. https://doi.org/10.1016/j. jece.2016.09.023.

Anbia, M., \& Salehi, S. (2012). Removal of acid dyes from aqueous media by adsorption onto amino-functionalized nanoporous silica SBA-3. Dyes and Pigments, 94, 1-9. https://doi.org/10.1016/j.dyepig.2011.10.016.

Arellano-Cárdenas, S., López-Cortez, S., Cornejo-Mazón, M., \& Mares-Gutiérrez, J. C. (2013). Study of malachite green adsorption by organically modified clay using a batch method. Applied Surface Science, 280, 74-78. https://doi. org/10.1016/j.apsusc.2013.04.097.

Banaei, A., Samadi, S., Karimi, S., Vojoudi, H., Pourbasheer, E., \& Badiei, A. (2017). Synthesis of silica gel modified with 2, 2'-(hexane-1,6-diylbis(oxy)) dibenzaldehyde as a new adsorbent for the removal of Reactive Yellow 84 and Reactive Blue 19 dyes from aqueous solutions: equilibrium and thermodynamic studies. Powder Technology, 319, 60-70. https://doi.org/10.1016/j.powtec.2017.06.044.

Bello, O. S., Adegoke, K. A., Olaniyan, A. A., \& Abdulazeez, H. (2015). Dye adsorption using biomass wastes and natural adsorbents: overview and future prospects. Desalination and Water Treatment, 56, 1292-1315. https://doi. org/10.1080/19443994.2013.862028.

Bendaho, D., Driss, T. A., \& Bassou, D. (2017). Adsorption of acid dye onto activated Algerian clay. Bulletin of the Chemical Society of Ethiopia, 31, 51-62. https://doi. org/10.4314/bcse.v31i1.5.

Bharathi, K. S., \& Ramesh, S. T. (2013). Removal of dyes using agricultural waste as low-cost adsorbents: a review. Applied Water Science, 3, 773-790. https://doi.org/10.1007/s13201013-0117-y.

Calvete, T., Lima, E. C., Cardoso, N. F., Dias, S. L. P., \& Pavan, F. A. (2009). Application of carbon adsorbents prepared from the Brazilian pine-fruit-shell for the removal of Procion Red MX 3B from aqueous solution-Kinetic, equilibrium, and 
thermodynamic studies. Chemical Engineering Journal, 155, 627-636. https://doi.org/10.1016/j.cej.2009.08.019.

Chaari, I., Fakhfakh, E., Chakroun, S., Bouzid, J., Boujelben, N., Feki, M., Rocha, F., \& Jamoussi, F. (2008). Lead removal from aqueous solutions by a Tunisian smectitic clay. Journal of Hazardous Materials, 156, 545-551. https://doi. org/10.1016/j.jhazmat.2007.12.080.

Chaari, I., Fakhfakh, E., Medhioub, M., \& Jamoussi, F. (2019). Comparative study on adsorption of cationic and anionic dyes by smectite rich natural clays. Journal of Molecular Structure, 1179, 672-677. https://doi.org/10.1016/j. molstruc.2018.11.039.

Chang, J., Ma, J., Ma, Q., Zhang, D., Qiao, N., Hu, M., \& Ma, H. (2016). Adsorption of methylene blue onto Fe3O4/activated montmorillonite nanocomposite. Applied Clay Science, 119, 132-140. https://doi.org/10.1016/j.clay.2015.06.038.

Chicinas, R. P., Bedelean, H., Stefan, R., \& Maicaneanu, A. (2018). Ability of a montmorillonitic clay to interact with cationic and anionic dyes in aqueous solutions. Journal of Molecular Structure, 1154, 187-195. https://doi.org/10.1016 j. molstruc.2017.10.038.

Dotto, G. L., Rodrigues, F. K., Tanabe, E. H., Fröhlich, R., Bertuol, D. A., Martins, T. R., \& Foletto, E. L. (2016). Development of chitosan/bentonite hybrid composite to remove hazardous anionic and cationic dyes from colored effluents. Journal of Environmental Chemical Engineering, 4, 3230-3239. https://doi.org/10.1016/j.jece.2016.07.004.

Dzieniszewska, A., Kyziol-Komosinska, J., \& Pajak, M. (2019). Effect of auxiliary substances on the adsorption of anionic dyes on low-moor peat. Desalination and Water Treatment, 177, 209-226. https://doi.org/10.5004/dwt.2020.24933.

Errais, E., Duplay, J., \& Darragi, F. (2010). Textile dye removal by natural clay - case study of Fouchana Tunisian clay. Environmental Technology, 31, 373-380. https://doi. org/10.1080/09593330903480080.

Errais, E., Duplay, J., Darragi, F., M'Rabet, I., Aubert, A., Huber, F., \& Morvan, G. (2011). Efficient anionic dye adsorption on natural untreated clay: kinetic study and thermodynamic parameters. Desalination, 275, 74-81. https://doi. org/10.1016/j.desal.2011.02.031.

Errais, E., Duplay, J., Elhabiri, M., Khodja, M., Ocampo, R., Baltenweck-Guyot, R., \& Darragi, F. (2012). Anionic RR120 dye adsorption onto raw clay: surface properties and adsorption mechanism. Colloids and Surfaces A: Physicochemical and Engineering Aspects, 403, 69-78. https://doi.org/10.1016/j.colsurfa.2012.03.057.

Foo, K. Y., \& Hameed, B. H. (2010). Insights into the modeling of adsorption isotherm systems. Chemical Engineering Journal, 156, 2-10. https://doi.org/10.1016/j.cej.2009.09.013.

Forgacs, E., Cserháti, T., \& Oros, G. (2004). Removal of synthetic dyes from wastewaters: a review. Environment International, 30, 953-971. https://doi.org/10.1016/j.envint.2004.02.001.

Franciski, M. A., Peres, E. C., Godinho, M., Perondi, D., Foletto, E. L., Collazzo, G. C., \& Dotto, G. L. (2018). Development of $\mathrm{CO}_{2}$ activated biochar from solid wastes of a beer industry and its application for methylene blue adsorption. Waste Management, 78, 630-638. https://doi.org/10.1016/j. wasman.2018.06.040.

Gadekar, M. R., \& Ahammed, M. M. (2015). Coagulation/ flocculation process for dye removal using water treatment residuals: modelling through artificial neural networks.
Desalination and Water Treatment, 57, 26392-26400. https://doi.org/10.1080/19443994.2016.1165150.

Gamoudi, S., \& Srasra, E. (2019). Adsorption of organic dyes by HDPy+-modified clay: effect of molecular structure on the adsorption. Journal of Molecular Structure, 1193, 522-531. https://doi.org/10.1016/j.molstruc.2019.05.055.

Gao, H., Zhao, S., Cheng, X., Wang, X., \& Zheng, L. (2013). Removal of anionic azo dyes from aqueous solution using magnetic polymer multi-wall carbon nanotube nanocomposite as adsorbent. Chemical Engineering Journal, 223, 84-90. https://doi.org/10.1016/j.cej.2013.03.004.

Genc, A., \& Oguz, A. (2010). Sorption of acid dyes from aqueous solution by using non-ground ash and slag. Desalination, 264, 78-83. https://doi.org/10.1016/j.desal.2010.07.007.

Gil, A., El Mouzdahir, Y., Elmchaouri, A., Vicente, M. A., \& Korili, S. A. (2013). Equilibrium and thermodynamic investigation of methylene blue adsorption on thermal- and acid-activated clay minerals. Desalination and Water Treatment, 51, 2881-2888. https://doi.org/10.1080/19443994.2012.748127.

Gürses, A., Doğar, Ç., Yalçın, M., Açıkyıldız, M., Bayrak, R., \& Karaca, S. (2006). The adsorption kinetics of the cationic dye, methylene blue, onto clay. Journal of Hazardous Materials, 131, 217-228. https://doi.org/10.1016/j. jhazmat.2005.09.036.

Hai, Y., Li, X., Wu, H., Zhao, S., Deligeer, W., \& Asuha, S. (2015). Modification of acid-activated kaolinite with $\mathrm{TiO} 2$ and its use for the removal of azo dyes. Applied Clay Science, 114, 558-567. https://doi.org/10.1016/j.clay.2015.07.010.

Hassan, M. M., \& Carr, C. M. (2018). A critical review on recent advancements of the removal of reactive dyes from dyehouse effluent by ion-exchange adsorbents. Chemosphere, 209, 201219. https://doi.org/10.1016/j.chemosphere.2018.06.043.

Hokkanen, S., Bhatnagar, A., Koistinen, A., Kangas, T., Lassi, U., \& Sillanpää, M. (2018). Comparison of adsorption equilibrium models and error functions for the study of sulfate removal by calcium hydroxyapatite microfibrillated cellulose composite. Environmental Technology, 39, 952-966. https://doi.org/10.1080/09593330.2017.1317839.

Huang, J., Liu, Y., Jin, Q., Wang, X., \& Yang, J. (2007). Adsorption studies of a water soluble dye, Reactive Red MF-3B, using sonication-surfactant-modified attapulgite clay. Journal of Hazardous Materials, 143, 541-548. https://doi.org/10.1016/j.jhazmat.2006.09.088.

Hycnar, E., Mucha, J., Ratajczak, T., \& Wasilewska-Błaszczyk, M. (2018). The assessment of usefulness of limestones from the Kleszczów Graben (Bełchatów lignite deposit Szczerców field) as potential $\mathrm{SO}_{2}$ sorbents in the power industry - problems of geological documenting. Biuletyn Państwowego Instytutu Geologicznego, 472, 311-320. https://doi.org/10.5604/01.3001.0012.6876.

Jain, A. K., Gupta, V. K., Bhatnagar, A., \& Suhas. (2003). Utilization of industrial waste products as adsorbents for the removal of dyes. Journal of Hazardous Materials, 101, 3142. https://doi.org/10.1016/S0304-3894(03)00146-8.

Jasper, E. E., Ajibola, V. O., \& Onwuka, J. C. (2020). Nonlinear regression analysis of the sorption of crystal violet and methylene blue from aqueous solutions onto an agro-waste derived activated carbon. Applied Water Science, 10(0). https://doi.org/10.1007/s13201-020-01218-y.

Kausar, A., Iqbal, M., Javed, A., Aftab, K., Nazli, Z.-i.-H., Bhatti, H. N., \& Nouren, S. (2018). Dyes adsorption using clay and 
modified clay: A review. Journal of Molecular Liquids, 256, 395-407. https://doi.org/10.1016/j.molliq.2018.02.034.

Kim, T.-H., Park, C., \& Kim, S. (2005). Water recycling from desalination and purification process of reactive dye manufacturing industry by combined membrane filtration. Journal of Cleaner Production, 13, 779-786. https://doi. org/10.1016/j.jclepro.2004.02.044.

Krysztafkiewicz, A., Binkowski, S., \& Jesionowski, T. (2002). Adsorption of dyes on a silica surface. Applied Surface Science, 199, 31-39. https://doi.org/10.1016/S0169-4332 (02)00248-9.

Kumar, K. V., \& Sivanesan, S. (2005). Comparison of linear and non-linear method in estimating the sorption isotherm parameters for safranin onto activated carbon. Journal of Hazardous Materials, 123, 288-292. https://doi. org/10.1016/j.jhazmat.2005.03.040.

Kyziol-Komosinska, J., Rosik-Dulewska, C. Z., Pajak, M., \& Jarzyna, M. (2010). Removal of direct dyes from wastewater by sorption onto smectite-clay. Archives of Environmental Protection, 36, 3-14.

Kyziol-Komosinska, J., Rosik-Dulewska, C. Z., Dzieniszewska, A., \& Pajak, M. (2018). Low-moor peats as biosorbents for removal of anionic dyes from water. Fresenius Environmental Bulletin, 27, 6-20.

Labanda, J., Sabaté, J., \& Llorens, J. (2011). Experimental and modeling study of the adsorption of single and binary dye solutions with an ion-exchange membrane adsorber. Chemical Engineering Journal, 166, 536-543. https://doi. org/10.1016/j.cej.2010.11.013.

Madejova, J., Bujdak, J., Janek, M., \& Komadel, P. (1998). Comparative FT-IR study of structural modifications during acid treatment of dioctahedral smectites and hectorite. Spectrochimica Acta A, 54, 1397-1406.

Malakootian, M., Mansoorian, H. J., Hosseini, A., \& Khanjani, N. (2015). Evaluating the efficacy of alumina/carbon nanotube hybrid adsorbents in removing Azo Reactive Red 198 and Blue 19 dyes from aqueous solutions. Process Safety and Environment Protection, 96, 125-137. https://doi. org/10.1016/j.psep.2015.05.002.

Mirzaei, N., Hadi, M., Gholami, M., Fard, R. F., \& Aminabad, M. S. (2016). Sorption of acid dye by surfactant modificated natural zeolites. Journal of the Taiwan Institute of Chemical Engineers, 59, 186-194. https://doi.org/10.1016/j. jtice.2015.07.010.

Mishra, S., \& Maiti, A. (2019). Study of simultaneous bioremediation of mixed reactive dyes and $\mathrm{Cr}(\mathrm{VI})$ containing wastewater through designed experiments. Environmental Monitoring and Assessment, 191, 766. https://doi. org/10.1007/s10661-019-7976-0.

Mishra, S., \& Maiti, A. (2020). Biological methodologies for treatment of textile wastewater. In R. Singh, P. Shukla, \& P. Singh (Eds.), Environmental Processes and Management. Water Science and Technology Library vol 91. Cham: Springer. https://doi.org/10.1007/978-3-030-38152-3_6.

Mishra, S., Nayak, J. K., \& Maiti, A. (2020). Bacteria-mediated bio-degradation of reactive azo dyes coupled with bio-energy generation from model wastewater. Clean Technologies and Environmental Policy, 22, 651-667. https://doi.org/10.1007 /s10098-020-01809-y.

Mishra, S., Cheng, L., \& Maiti, A. (2021). The utilization of agrobiomass/byproducts for effective bio-removal of dyes from dyeing wastewater: a comprehensive review. Journal of Environmental Chemical Engineering, 9, 104901. https://doi.org/10.1016/j.jece.2020.104901.

Nebaghe, K. C., El Boundati, Y., Ziat, K., Naji, A., Rghioui, L., \& Saidi, M. (2016). Comparison of linear and non-linear method for determination of optimum equilibrium isotherm for adsorption of copper(II) onto treated Martil sand. Fluid Phase Equilibria, 430, 188-194. https://doi.org/10.1016/j. fluid.2016.10.003.

Nejib, A., Joelle, D., Fadhila, A., Sophie, G., \& Malika, T.-A. (2015). Adsorption of anionic dye on natural and organophilic clays: effect of textile dyeing additives. Desalination and Water Treatment, 54, 1754-1769. https://doi.org/10.1080/19443994.2014.895781.

Nethaji, S., Sivasamy, A., \& Mandal, A. B. (2013). Adsorption isotherms, kinetics and mechanism for the adsorption of cationic and anionic dyes onto carbonaceous particles prepared from Juglans regia shell biomass. International journal of Environmental Science and Technology, 10, 231-242. https://doi.org/10.1007/s13762-012-0112-0.

Ngulube, T., Gumbo, J. R., Masindi, V., \& Maity, A. (2017). An update on synthetic dyes adsorption onto clay based minerals: a state-of-art review. Journal of Environmental Management, 191, 35-57. https://doi.org/10.1016/j. jenvman.2016.12.031.

Omer, O. S., Hussein, M. A., Hussein, B. H. M., \& Mgaidi, A. (2018). Adsorption thermodynamics of cationic dyes (methylene blue and crystal violet) to a natural clay mineral from aqueous solution between 293.15 and 323.15 K. Arabian Journal of Chemistry, 11, 615-623. https://doi.org/10.1016 j.arabjc.2017.10.007.

Özcan, A. S., Erdem, B., \& Özcan, A. (2004). Adsorption of Acid Blue 193 from aqueous solutions onto $\mathrm{Na}$-bentonite and DTMA-bentonite. Journal of Colloid and Interface Science, 280, 44-54. https://doi.org/10.1016/j. jcis.2004.07.035.

Özcan, A. S., Tetik, S., \& Özcan, A. (2005). Adsorption Of Acid Dyes From Aqueous Solutions Onto Sepiolite. Separation Science and Technology, 39, 301-320. https://doi. org/10.1081/SS-120027560.

Öztop, B., \& Shahwan, T. (2006). Modification of a montmorillonite-illite clay using alkaline hydrothermal treatment and its application for the removal of aqueous Cs+ ions. Journal of Colloid and Interface Science, 295, 303-309. https://doi.org/10.1016/j.jcis.2005.12.008.

Pajak, M., \& Dzieniszewska, A. (2020). Evaluation of the metallurgical dust sorbent efficacy in Reactive Blue 19 dye removal from aqueous solutions and textile wastewater. Environmental Engineering Science, 37. https://doi. org/10.1089/ees.2019.0410.

Pajak, M., Dzieniszewska, A., \& Kyziol-Komosinska, J. (2019). Sorption of Acid Black 1 dye onto bentonite - equilibrium and kinetic studies. Journal of Environmental Science and Health, Part A, 54, 1-10. https://doi.org/10.1080 /10934529.2019.1631654.

Raghu, S., Lee, C. W., Chellammal, S., Palanichamy, S., \& Basha, C. A. (2009). Evaluation of electrochemical oxidation techniques for degradation of dye effluents-a comparative approach. Journal of Hazardous Materials, 171, 748-754. https://doi.org/10.1016/j.jhazmat.2009.06.063. 
Robinson, T., McMullan, G., Marchant, R., \& Nigam, P. (2001). Remediation of dyes in textile effluent: a critical review on current treatment technologies with a proposed alternative. Bioresource Technology, 77, 247-255. https://doi. org/10.1016/S0960-8524(00)00080-8.

Saffaj, N., Loukili, H., Alami Younssi, S., Albizane, A., Bouhria, M., Persin, M., \& Larbot, A. (2004). Filtration of solution containing heavy metals and dyes by means of ultrafiltration membranes deposited on support made of Moroccan clay. Desalination, 168, 301-306. https://doi.org/10.1016/j. desal.2004.07.013.

Santos, S. C. R., \& Boaventura, R. A. R. (2016). Adsorption of cationic and anionic azo dyes on sepiolite clay: equilibrium and kinetic studies in batch mode. Journal of Environmental Chemical Engineering, 4, 1473-1483. https://doi. org/10.1016/j.jece.2016.02.009.

Saruchi Kumar, V. (2019). Adsorption kinetics and isotherms for the removal of rhodamine $\mathrm{B}$ dye and $\mathrm{Pb}+2$ ions from aqueous solutions by a hybrid ion-exchanger. Arabian Journal of Chemistry, 12, 316-329. https://doi.org/10.1016/j. arabjc.2016.11.009.

Soni, V. K., Roy, T., Dhara, S., Choudhary, G., Sharm, P. R., \& Sharma, R. K. (2018). On the investigation of acid and surfactant modification of natural clay for photocatalytic water remediation. Journal of Materials Science, 53, 10095-10110. https://doi.org/10.1007/s10853-018-2308-2.

Stoch, L., Bahranowski, K., Budek, L., \& Fijał, J. (1977). Bleaching properties of non-bentonitic clay materials and their modification. Mineralogia Polonica, 8, 31-49.

Szygula, A., Guibal, E., Palacín, M. A., Ruiz, M., \& Sastre, A. M. (2009). Removal of an anionic dye (Acid Blue 92) by coagulation-flocculation using chitosan. Journal of
Environmental Management, 90, 2979-2986. https://doi. org/10.1016/j.jenvman.2009.04.002.

Tamayo, A., Kyziol-Komosinska, J., Sánchez, M. J., Calejas, P., Rubio, J., \& Barba, M. F. (2012). Characterization and properties of treated smectites. Journal of the European Ceramic Society, 32, 2831-2841. https://doi.org/10.1016/j. jeurceramsoc.2011.12.029.

Tanyildizi, M. S. (2011). Modeling of adsorption isotherms and kinetics of reactive dye from aqueous solution by peanut hull. Chemical Engineering Journal, 168, 1234-1240. https://doi. org/10.1016/j.cej.2011.02.021.

Ventura-Camargo, B. C., \& Marin-Morales, M. A. (2013). Azo dyes: characterization and toxicity - a review. Textiles and Light Industrial Science and Technology, 2, 85-103.

Vieira, M. L. G., Esquerd, V. M., Nobre, L. R., Dotto, G. L., \& Pinto, L. A. A. (2014). Glass beads coated with chitosan for the food azo dyes adsorption in a fixed bed column. Journal of Industrial and Engineering Chemistry, 20, 3387-3393. https://doi.org/10.1016/j.jiec.2013.12.024.

Wawrzkiewicz, M., Wisniewska, M., Gun'ko, V. M., \& Zarko, V. I. (2015). Adsorptive removal of acid, reactive and direct dyes from aqueous solutions and wastewater using mixed silica-alumina oxide. Powder Technology, 278, 306-315. https://doi.org/10.1016/j.powtec.2015.03.035.

Yadav, M., \& Singh, N. K. (2017). Isotherm investigation for the sorption of fluoride onto Bio-F: comparison of linear and non-linear regression method. Applied Water Science, 7, 4793-4800. https://doi.org/10.1007/s13201-017-0602-9.

Publisher's Note Springer Nature remains neutral with regard to jurisdictional claims in published maps and institutional affiliations. 